\title{
Migração partidária nos municípios brasileiros (2000-2016)
}

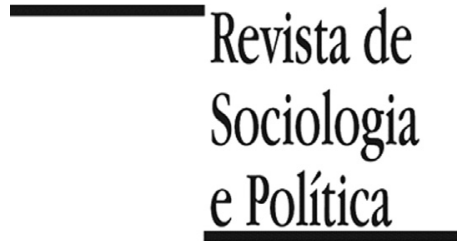

DOI 10.1590/1678-987318266605

\author{
Marco Antonio Faganello' iD e \\ Jean Lucas Macedo Fernandes" ic
}

RESUMO Introdução: O objetivo do trabalho é investigar a dinâmica das migrações partidárias em nível local, entre 2000 e 2016 , tendo como escopo as eleições para prefeito e vereador, em todo o Brasil. A migração partidária é bastante explorada em nível nacional, sobretudo para o Congresso Nacional, mas em nível local esse fenômeno tem recebido pouca atenção da literatura. Métodos: A metodologia utilizada é quantitativa, com informações do Tribunal Superior Eleitoral (TSE), valendo-se de ferramentas da geografia eleitoral, da análise de redes e de estatística descritiva. Resultados: A migração partidária e de candidaturas (políticos que concorrem a prefeito em uma eleição e na seguinte para vereador, e vice-versa) não trazem, necessariamente, maiores chances de sucesso. Observa-se, também, que no nível local as taxas de migrações vêm decaindo, nos dois cargos. Discussão: Muito se argumenta acerca da "fraqueza" dos laços partidários nos municípios e de uma relação pouco estável entre candidatos e partidos. Estes seriam trocados pelos políticos a todo momento, sempre que o contexto local fosse favorável. Sob esse ponto de vista, a migração partidária em nível municipal seria determinada for fatores circunstanciais. Contudo, os achados obtidos nesse artigo revelam que há padrões de comportamento dos candidatos e partidos nos municípios em termos de estratégias eleitorais, e que a variação nos indicadores da migração não é ad hoc. Nesse sentido, apontamos para outra realidade: os partidos seguem estratégias distintas e coordenadas, em se tratando de migrar ou não.

PALAVRAS-CHAVE: partidos políticos; municípios; política local, prefeitos, vereadores.

Recebido em 25 de Setembro de 2016. Aceito em 18 de Janeiro de 2017.

\section{Introdução: o contexto do fenômeno no Brasil ${ }^{1}$}

\author{
${ }^{1}$ Agradecemos aos \\ comentários e sugestões dos \\ pareceristas anônimos da \\ Revista de Sociologia e \\ Política.
}

${ }^{2}$ A lista de siglas está disponível em Apêndice (Tabela 1A).

\begin{abstract}
A migração partidária no Brasil possui dois momentos distintos na se um período de reacomodação partidária, no bojo do fim do regime militar e do bipartidarismo. Neste contexto, que durou até as eleições de 1994, a migração poderia ser explicada por fatores conjunturais, como a própria transição democrática, que possibilitou a criação de novos partidos e as trocas de legenda realizadas pelos parlamentares. Estes procuravam não apenas apagar suas relações com o passado político autoritário (no caso daqueles vinculados à ARENA $^{2}$, partido pró-governo militar), mas também se reacomodar, em um contexto em que a imposição do bipartidarismo não mais existia - como foi o caso dos políticos do oposicionista MDB, que abrigava um mosaico ideológico bastante diversificado em seu interior (Kinzo 1988). A fragilidade institucional e a falta de coesão desses partidos (Mainwaring 1991; Ames 2003), bem como a excessiva liberalização da legislação, também foram apontados pela literatura como causas para a migração partidária intensa (Lamounier \& Meneguello 1986; Lima Júnior 1993). Prevalecia o argumento de que a migração partidária seria um fenômeno próprio do sistema político brasileiro, fruto da indisciplina parlamentar e dos laços clientelistas dos políticos (Mainwaring 1991; Lamounier 1994; Ames 2003).
\end{abstract}

Após 1994, esses aspectos conjunturais associados à transição e à necessidade de reacomodação das lideranças partidárias já não estavam mais tão evidentes. Isso acabou por tornar a troca de legenda um processo mais complexo de se entender e associado a diversos fatores, como as mudanças nas regras 
${ }^{3}$ Para uma revisão desses trabalhos, ver Melo (2004) e Freitas (2008). eleitorais e partidárias - em termos de maior ou menor permissibilidade às migrações (Freitas 2012).

É a partir deste momento de maior estabilidade política que pretendemos analisar as migrações partidárias nos municípios brasileiros. Os trabalhos em torno do tema focam majoritariamente o Congresso e, de modo mais específico, a Câmara dos Deputados ${ }^{3}$. Tendo os achados dessas pesquisas como ponto de partida, procuraremos observar em que medida eles ganham respaldo no nível local. O eixo principal de análise parte das seguintes perguntas: quais são os padrões de migração partidária em nível local? De que maneira os partidos e candidatos atuam nessa esfera, durante os pleitos municipais?

Acreditamos que há coordenação política exercida pelos partidos e lideranças nos três níveis de governo (Carneiro \& Almeida 2008). A hipótese central é que a política local não está isolada das demais dinâmicas e competições políticas que ocorrem estadual e nacionalmente ${ }^{4}$. Nesse sentido, um dos argumentos que defenderemos é que a política local corresponde, em grande medida, a fenômenos e padrões que são observados nas demais esferas governativas (Trounstine 2009). Além disso, defendemos que os partidos em nível local também agem de forma estratégica e direcionada, não sendo meros partidos cartoriais, nos quais lideranças entram e saem aleatoriamente. Demonstramos empiricamente, então, que os partidos são organizações relevantes e capazes de estruturar a competição localmente.

Para construirmos essas argumentações, analisaremos o comportamento de candidatos a prefeito e a vereador, entre as eleições municipais de 2000 e 2016. Observaremos como se dão as migrações, tanto de partidos quanto de candidaturas (candidatos a vereador que passam a concorrer pelas prefeituras e viceversa), e a maneira como os partidos respondem a este fenômeno. A divisão ideológica das agremiações é um aspecto importante que será levado em consideração, de modo a apontar como essas organizações articulam as ideologias com suas atuações na esfera municipal. Uma conclusão geral a que chegamos é que há lógicas e padrões de comportamento político-partidários nos municípios, o que nos leva a compreender a organização partidária sob um novo prisma: como um elemento fundamental para a consolidação das estratégias de lideranças locais ou regionais.

O texto se encontra dividido da seguinte maneira: primeiramente, levantamos algumas considerações gerais sobre a migração partidária, procurando dialogar com a literatura recente e estabelecendo, assim, os parâmetros de análise e hipóteses. Na sequência, são feitas algumas observações de caráter metodológico, destacando a forma como tratamos os dados. Em terceiro lugar, são apresentados os dados coletados das eleições municipais, para os cargos de vereador e prefeito. Tendo em vista as especificidades do poder local e dos processos de socialização de suas elites (Kerbauy 2005), o recorte metodológico engloba apenas as candidaturas de nível local - prefeitos e vereadores que concorrem nas eleições nacionais, após dois anos, por exemplo, não foram contabilizados $^{5}$. Por fim, após a exposição e análise dos dados, é feita uma conclusão que procura comparar os achados com as pesquisas já desenvolvidas sobre o tema, bem como apresentar algumas tendências político-partidárias dos municípios brasileiros.

\section{A migração partidária e alguns debates da literatura recente}

5 Afinal, os municípios têm passado por "um período de reconfiguração da arena decisória e dos processos de tomada de decisão,
Segundo Laver e Benoit (2003), os estudos sobre migração partidária têm enfocado muito a racionalidade dos migrantes, mas ignoram os incentivos dos partidos para os quais eles estão sendo atraídos. Trazendo este ponto, acreditamos que há um duplo eixo a ser considerado na migração partidária. Por um 
convivendo com duas lógicas distintas e contraditórias: (1) o tradicionalismo e as ações clientelistas que sempre caracterizaram o poder local e (2) os procedimentos universais que caracterizariam ações mais inovadoras das lideranças locais" (Kerbauy 2005, p.362). lado, a troca de legenda é uma oportunidade para que o político maximize suas chances de sucesso na carreira (Melo 2004). Porém, há de se considerar também, como variável explicativa, a estratégia partidária: os partidos também buscam atrair políticos e oferecer recompensas (Laver \& Benoit 2003; Desposato 2006). Assim, a troca de legenda é vista como uma via de mão dupla, capaz de beneficiar não apenas o parlamentar - que pode ter diversos objetivos, como a maximização de seu sucesso eleitoral, ocupar cargos e obter recursos do Estado - mas também o partido que o acolhe e que visa a expansão de seu eleitorado e de sua máquina (Freitas 2012).

Freitas (2008) argumenta que tomar como objetivo central da migração a motivação individual do parlamentar é problemático, na medida em que se trata de uma avaliação subjetiva e de difícil mensuração. Além disso:

"O acento na decisão e motivação individual do parlamentar faz com que os analistas desconsiderem o peso dos demais atores envolvidos neste processo. Basicamente, parte-se do princípio que os partidos políticos no Brasil são pouco importantes e que a migração partidária comprovaria esta afirmação. O papel dos partidos políticos nas trocas de legenda é inteiramente desconsiderado. Quando muito, os partidos políticos são tomados como vítimas de uma estratégia ultra-individualista dos parlamentares. Mas se no sistema político brasileiro os partidos não importam, ou importam tão pouco que os parlamentares podem entrar e sair deles quando quiserem, por que os parlamentares se dariam ao trabalho de trocar de partido? Tamanha independência parece incoerente com um sistema no qual as regras são extremamente centralizadas em torno dos partidos políticos. Dito de outra forma, não faz sentido trocar de partido se os partidos não forem capazes de oferecer benefícios para os seus membros (Freitas 2008, pp.5-6).

Portanto, nesta troca entre parlamentares e partidos, os movimentos são calculados e racionais para ambos. Os partidos se tornam atores centrais, sendo alvos das estratégias dos políticos e também atuando sobre eles. Desposato (2006) argumenta que há dois benefícios básicos quando os partidos aceitam novos membros: aumento no tamanho da bancada e incremento no suporte eleitoral, trazido pelos migrantes. Estes, por sua vez, escolhem partidos que irão facilitar suas reeleições - ou ao menos propiciar acesso a cargos, recursos e influência.

A importância dos partidos em nível local, como apontada por Borges (2010) no que se refere à coordenação entre município e as demais instâncias governativas $^{6}$, pode ser vista também em termos organizativos. De acordo com Ames (1994), há uma relação fundamental de interdependência entre o Executivo nacional e as prefeituras, em termos de apoio político, por um lado, e repasse de verbas, por outro. Nesse sentido, a presença de máquinas partidárias fortes é importante para que os políticos sejam capazes de influenciar as decisões e as dinâmicas políticas locais. Portanto, o argumento deste trabalho caminha na direção de reconhecer o partido em nível local como um ator central para as relações entre as elites políticas, a articulação de seus interesses e as estratégias eleitorais que buscam nos pleitos.

Melo (2004), em estudo sobre a Câmara dos Deputados, encontrou que a migração na direita tende a ser mais acentuada e intrabloco - ou seja, os deputados pertencentes a um partido de direita migram para outro do mesmo campo ideológico. Na esquerda, há uma menor tendência à migração - porém, mais de um terço dos migrantes foi para partidos de direita. Desposato (2006) também chama atenção para a importância da compatibilidade ideológica na hora de escolher um partido. Nesse sentido, o grau de liberdade para a troca de legenda não é absoluto (Diniz 2000), mas segue minimamente um padrão comportamental e ideológico. 
Sobre o desempenho eleitoral, Schmitt (1999) demonstra que as chances de reeleição de um deputado migrante são menores. Para Melo (2004), as mudanças de partido não melhoram as chances de sucesso eleitoral dos parlamentares e nem tampouco tendem a piorá-las - a não ser quando se abandonam partidos de esquerda ou partidos governistas em direção à oposição. Por fim, a dimensão regional também parece não impactar os padrões de migração. Segundo Diniz (2000) e Melo (2004), regiões mais e menos desenvolvidas não apresentam tendências distintas de migração. Uma hipótese testada e refutada era que as regiões menos desenvolvidas (Norte, Nordeste e Centro-Oeste) migrariam mais do que as mais desenvolvidas (Sul e Sudeste).

As conclusões dessas pesquisas anteriores nos fornecem importantes diretrizes para se pensar os padrões do fenômeno da migração local e em que medida ele está associado aos demais níveis de governo. Nosso objetivo é produzir uma investigação exploratória sobre a migração na esfera local e verificar se os mesmos padrões encontrados nos trabalhos anteriores na esfera federal (Diniz 2000; Desposato 2006; Melo 2004; Schmitt 1999) se repetem. Em primeiro lugar, iremos proceder a uma descrição das taxas de migração e de suas variações regionais. Em seguida, ancorados na literatura, analisaremos as trocas de legenda no nível local a partir de três eixos exploratórios: 1) o impacto da migração sobre o sucesso eleitoral dos políticos; 2) as consequências dos diferentes níveis de desenvolvimento socioeconômico das regiões sobre as trocas de legenda; 3) a tendência de migração intrablocos ideológicos, delimitando as fronteiras entre direita, centro e esquerda.

\section{Observações metodológicas e tratamento dos dados}

${ }^{7}$ Nosso recorte temporal abrange, portanto, quatro pares de eleições, em todos os municípios do país: 2000-2004; 2004-2008; 2008-2012; 2012-2016).
Dado o grande número de candidatos e de municípios, a aferição de uma taxa de migração que envolva todos os políticos de um determinado partido, em todos os municípios e ao longo do tempo, traz alguns desafios. Para resolver este problema, desenvolvemos a seguinte técnica: em primeiro lugar, mapeamos o número do CPF dos candidatos, presente nos bancos de dados de votação do Tribunal Superior Eleitoral (TSE) desde o ano $2000^{7}$; em seguida, verificamos quais candidatos se faziam presentes em duas eleições municipais consecutivas. A partir desse universo de candidatos sophomores (que concorrem em duas eleições consecutivas)analisamos a filiação partidária de cada candidatura, em cada uma das eleições consecutivas analisadas.

Assim, por exemplo, se a filiação de um candidato a vereador sophomore nas eleições de 2000 e 2004 fosse diferente, ou seja, se ele estivesse concorrendo nessas eleições por partidos distintos, determinamos que este candidato migrou de partido (Migrante). Pelo contrário, caso a filiação fosse a mesma, o candidato em questão não teria migrado (Não Migrante).

Por esse modelo, não conseguimos verificar a condição de um candidatos quanto à migração caso ele participe de uma eleição municipal, mas não da anterior. Entendemos que a grande maioria dos casos desse tipo corresponde a candidatos que estão iniciando sua carreira política, sem estarem atrelados a nenhum outro partido diferente no passado. Chamaremos este tipo de candidato de freshman. É evidente que alguns casos podem não ser verdadeiros: eles podem indicar que o candidato não esteve na eleição anterior por ser um candidato eleito para o cargo de deputado estadual, federal ou senador; ou mesmo por ser um dirigente partidário sem relação com cargos políticos. No entanto, dado o tamanho do nosso banco de dados, que corresponde a quase dois milhões de observações, e por constatarmos que esses casos são a uma minoria, entendemos que essas perdas de informação não produzem viés na apresentação dos dados. Com esta abordagem, conseguimos trabalhar com uma quantidade significativa de dados em um espaço de tempo factível, garantindo a possibi- 
lidade de entender os processos migratórios entre candidatos a partir de uma visão global.

Muitos políticos sophomores decidem concorrer a cargos distintos, entre uma eleição e outra. Alguns candidatos à prefeito, em uma eleição, concorreram como vereador na eleição anterior, e vice-versa. A Tabela 1 descreve nosso banco de dados, com o total de candidaturas e municípios analisados, e a proporção de candidatos sophomores, freshman e os que concorrem em duas eleições consecutivas para o mesmo cargo (SMC) ou em cargos diferentes (SCD). O alto número de candidatos a vereador que concorrem em duas eleições para o mesmo cargo já era esperado, por conta do baixo custo das campanhas e da maior aproximação desses candidatos com seus eleitorados. A novidade ficou para a proporção de candidatos a prefeito que na eleição anterior concorreram como vereador. Em média, $24,7 \%$ dos candidatos a prefeito estiveram na eleição passada disputando uma vaga para as câmaras. Isso mostra que os cargos legislativos municipais são importantes para a coordenação das campanhas para o Executivo.

Para nossos objetivos, essa distinção entre cargos é importante na medida em que o fato de um candidato concorrer em cargos distintos pode funcionar como um viés para o cálculo de algumas avaliações empíricas. Candidatos nesta situação têm taxas de sucesso eleitoral diferentes dos que concorrem por cargos iguais, por exemplo. Em nossas análises, iremos apontar essas distinções sempre que entendermos que elas influenciam a totalidade dos dados descritos.

Por fim, para facilitar a análise dos partidos, a separação por blocos ideológicos obedeceu às classificações da literatura (Mainwaring, Meneguello \& Power 2000; Melo 2004; Power \& Zucco Jr. 2009; 2011; Codato, Bolognesi \& Roeder 2015). Reconhecemos a existência de controvérsias quanto à posição ideológica de alguns partidos - como PSDB e PMDB no centro ou na direita. Porém, comparando a partir das diversas perspectivas trazidas pelos autores que estudaram a fundo o tema, procuramos estabelecer as divisões mais recorrentes na literatura. Dividimos os partidos, então, da seguinte maneira ${ }^{8}$ (Tabela 2).

Tabela 1 - Dados descritivos do universo analisado

\begin{tabular}{lccccccc}
\hline Cargo & Eleição & Municípios & Candidaturas & Sophomores $(\%)$ & Freshman $(\%)$ & SMC $(\%)$ & SCD $(\%)$ \\
\hline Vereador & 2000 & 5.559 & 359.215 & - & - & - & - \\
& 2004 & 5.561 & 343.186 & 35,5 & 64,5 & 34,5 & 1,0 \\
& 2008 & 5.563 & 325.327 & 36,9 & 63,1 & 35,7 & 1,2 \\
& 2012 & 5.568 & 413.380 & 29,5 & 70,5 & 28,7 & 0,8 \\
\multirow{5}{*}{ Prefeito } & 2016 & 5.568 & 434.954 & 31,4 & 68,6 & 30,7 & 0,7 \\
& 2000 & 5.537 & 14.298 & - & - & - & - \\
& 2004 & 5.556 & 15.337 & 58,6 & 41,4 & 32,6 & 26,0 \\
& 2008 & 5.549 & 14.260 & 59,3 & 40,7 & 37,4 & 21,9 \\
& 2012 & 5.546 & 14.097 & 56,2 & 43,8 & 31,0 & 25,1 \\
\hline
\end{tabular}

Fonte: Os autores, a partir de dados do Tribunal Superior Eleitoral. Disponível em: http://www.tse.jus.br/eleicoes/estatisticas/repositorio-de-dados-eleitorais-1/repositorio-de-dados-eleitorais. Acesso em: 15 jan. 2018. Obs.: Não podemos identificar os candidatos Sophomores e Freshmen em 2000 pois o TSE não disponibiliza os registros de CPF dos candidatos na eleição de 1996. 
${ }^{8}$ As fusões e as separações partidárias foram consideradas na elaboração das bases de dados.
Tabela 2 - Separação dos partidos por blocos ideológicos

\begin{tabular}{|c|c|c|c|c|c|}
\hline \multicolumn{2}{|c|}{ Esquerda } & \multirow{2}{*}{$\begin{array}{l}\text { Centro } \\
\text { PMDB }\end{array}$} & \multicolumn{3}{|c|}{ Direita } \\
\hline PT & $\mathrm{PC}$ do $\mathrm{B}$ & & PAN & PRN & PSL \\
\hline PSTU & PCB & PMN & PFL/DEM & PRONA & PST \\
\hline \multirow[t]{5}{*}{ PSOL } & PCO & PSDB & PGT & PRP & PT do B \\
\hline & PDT & PV & PHS & PRTB & РTB \\
\hline & PSB & & PL/PR & PSC & PTN \\
\hline & & & $\mathrm{PPB} / \mathrm{PP}$ & PSD & PRB \\
\hline & & & PPS & PSDC & \\
\hline
\end{tabular}

Fontes: Mainwaring, Meneguello e Power (2000); Melo (2004); Power \& Zucco Jr. (2009; 2011); Codato, Bolognesi e Roeder (2015).

\section{Análise da migração partidária e seus efeitos}

As duas figuras do Gráfico 1 analisam as taxas percentuais de candidatos migrantes a vereador e prefeito, entre eleitos e entre o total de candidaturas. Em ambos os casos, as taxas tendem a variar na mesma direção, de acordo com o ano da eleição. Entre 2004 e 2012, os percentuais de migração estavam em declínio, mas voltam a se recuperar em 2016. Entre o gráfico com o total de eleitos (esquerda) e o de candidatos (direita), observa-se uma inversão nas taxas médias de migração entre prefeitos e vereadores. A taxa média do percentual de migrantes entre o total de candidaturas é maior entre prefeitos do que em vereadores; entre o total de eleitos, ocorre o contrário. Como as taxas de migração entre prefeitos eleitos e total de candidatura se apresentam muito próximas (ambas com 21\%), é de se supor que a inversão apresentada no segundo gráfico resulta do alto número de candidaturas a vereador que são incluídas no cálculo, fazendo com que as taxas de migração média nos anos analisados caiam bastante (de 26,7\% entre eleitos para 16,2\% entre candidaturas).

Gráfico 1 - Porcentagem de candidatos migrantes, por cargo (Brasil)
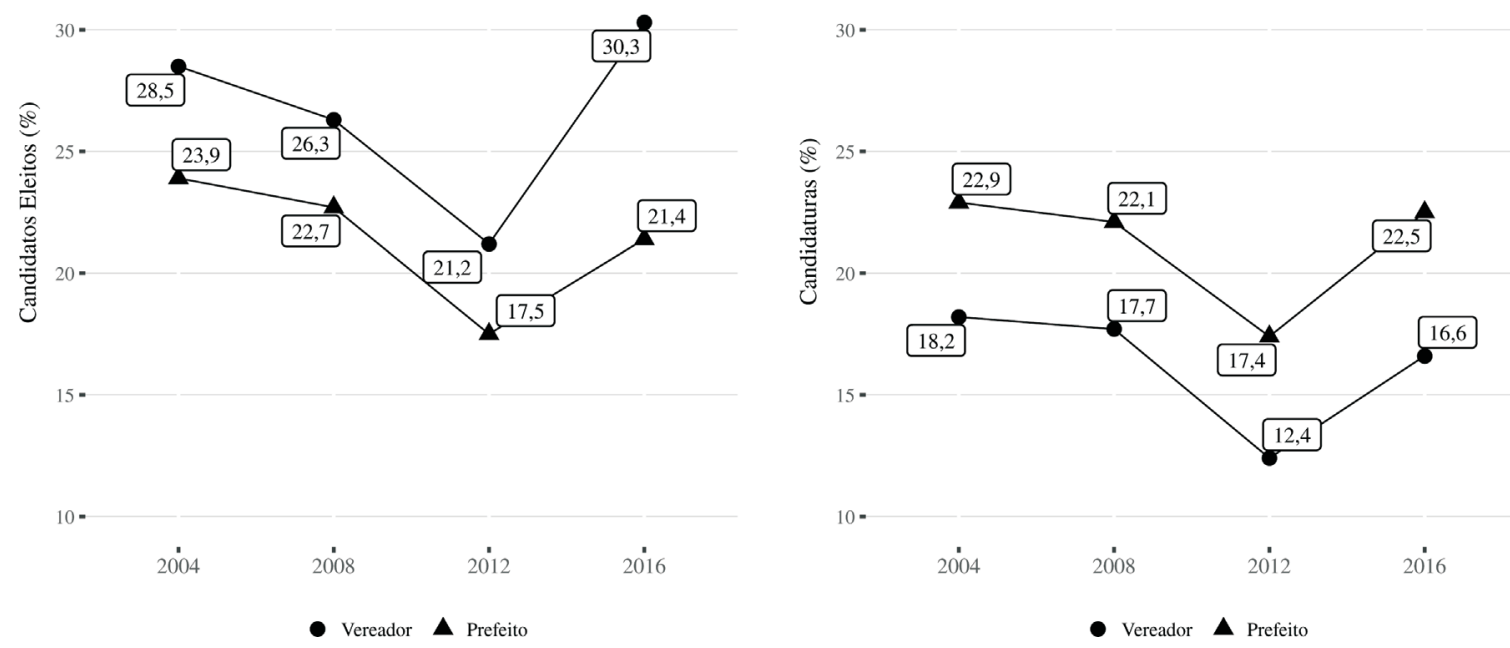

Fonte: Os autores, a partir de dados do Tribunal Superior Eleitoral. Disponível em: http://www.tse.jus.br/eleicoes/estatisticas/repositorio-de-dados-eleitorais-1/repositorio-de-dados-eleitorais. Acesso em: 15 jan. 2018. 
Salvas as devidas proporções, pode-se dizer que os padrões de migração partidária em nível local são mais voláteis. Como demonstraram Melo (2004) e Freitas (2012), na Câmara dos Deputados as migrações são bastante frequentes ao longo do tempo. Nossos dados também evidenciam uma grande quantidade de trocas de legenda entre os candidatos, mas com oscilações significativas entre os pleitos. Naturalmente, isso se deve, dentre outros fatores, à oferta bastante superior de cargos e de candidaturas e, também, às dinâmicas de competição local - que inserem uma série de desafios de coordenação das campanhas entre partidos e candidatos (Vasquez 2016).

Entre 2000 e 2010, observou-se uma relativa estabilidade do sistema partidário, sobretudo no nível nacional, onde não houve ampliação significativa da oferta partidária (Krause et al., 2016). Por outro lado, o efeito da legislação também pareceu incidir sobre a dinâmica das migrações nos municípios brasileiros. A Resolução 22.526/07 do TSE determinou que o mandato pertencia ao partido e não ao candidato - inibindo, assim, boa parte das trocas partidárias. $\mathrm{O}$ candidato que se desfilasse sem justa causa perderia o mandato por infidelidade partidária. Esta resolução gerou incertezas na Câmara dos Deputados (Freitas 2012) e pareceu incidir sobre as eleições municipais subsequentes, conforme os dados da Tabela 1.

A evidência do efeito da legislação sobre as taxas de migração fica mais nítida quando compreendemos que, no mesmo período, a oferta e o número efetivo de partidos cresceu de forma constante entre 2000 e 2016. Ou seja, era de se esperar que as taxas de migração acompanhassem a tendência de aumento da fragmentação partidária (Gráfico 2). Os dados do período mostram, portanto, que em um ambiente de aumento da oferta partidária, com maior desconcentração e aumento do número efetivo de partidos para vereador e prefeito, a legislação foi responsável por baixar as taxas de migração no período.

Ao avaliarmos essas mudanças partidárias, uma das perguntas que surge é: qual o impacto que elas trazem, em termos da obtenção de vitórias por parte daqueles que optam pela troca de legenda? O Gráfico 3 estabelece um comparativo da taxa de sucesso eleitoral entre prefeitos e vereadores que migraram e

Gráfico 2 - Número Efetivo de Partidos (NEP) por eleição e cargo (Brasil 2000-2016)

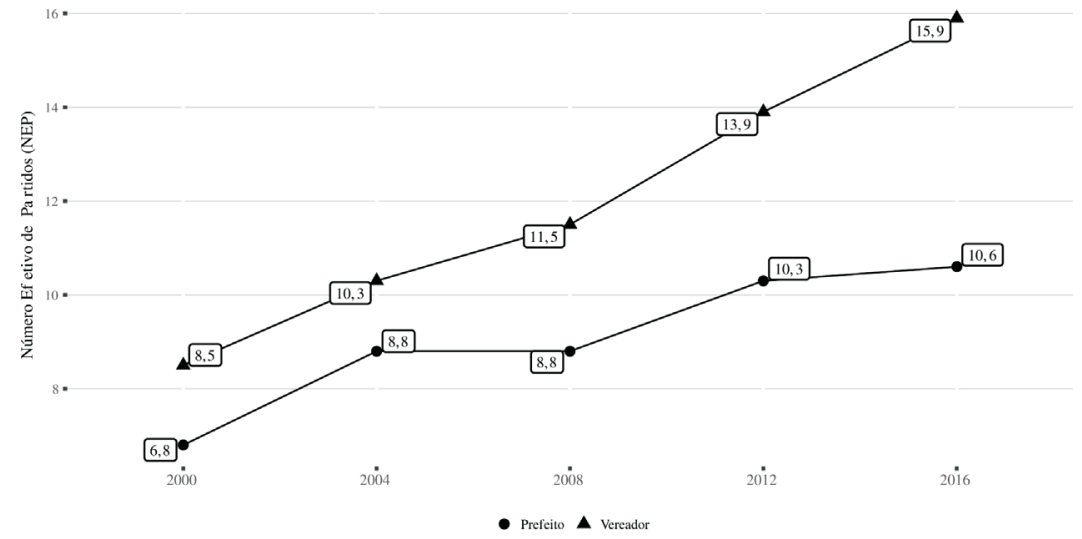

Fonte: Os autores, a partir de dados do Tribunal Superior Eleitoral. Disponível em: http://www.tse.jus.br/eleicoes/estatisticas/repositorio-de-dados-eleitorais-1/repositorio-de-dados-eleitorais. Acesso em: 15 jan. 2018.

Obs.: No cálculo do NEP, somam-se as porcentagens de votos obtidos por cada partido. As frações são elevadas ao quadrado e somadas. Divide-se o número 1 por essa soma (1/soma). Obtém-se um índice onde zero significa baixa fragmentação partidária e valores inteiros (1, 2, 3 etc.) representam, aproximadamente, o número de partidos relevantes (Laakso e Taagepera 1979). 
Gráfico 3 - Sucesso eleitoral dos candidatos a prefeito e vereador migrantes e não migrante (Brasil 2004-2016)
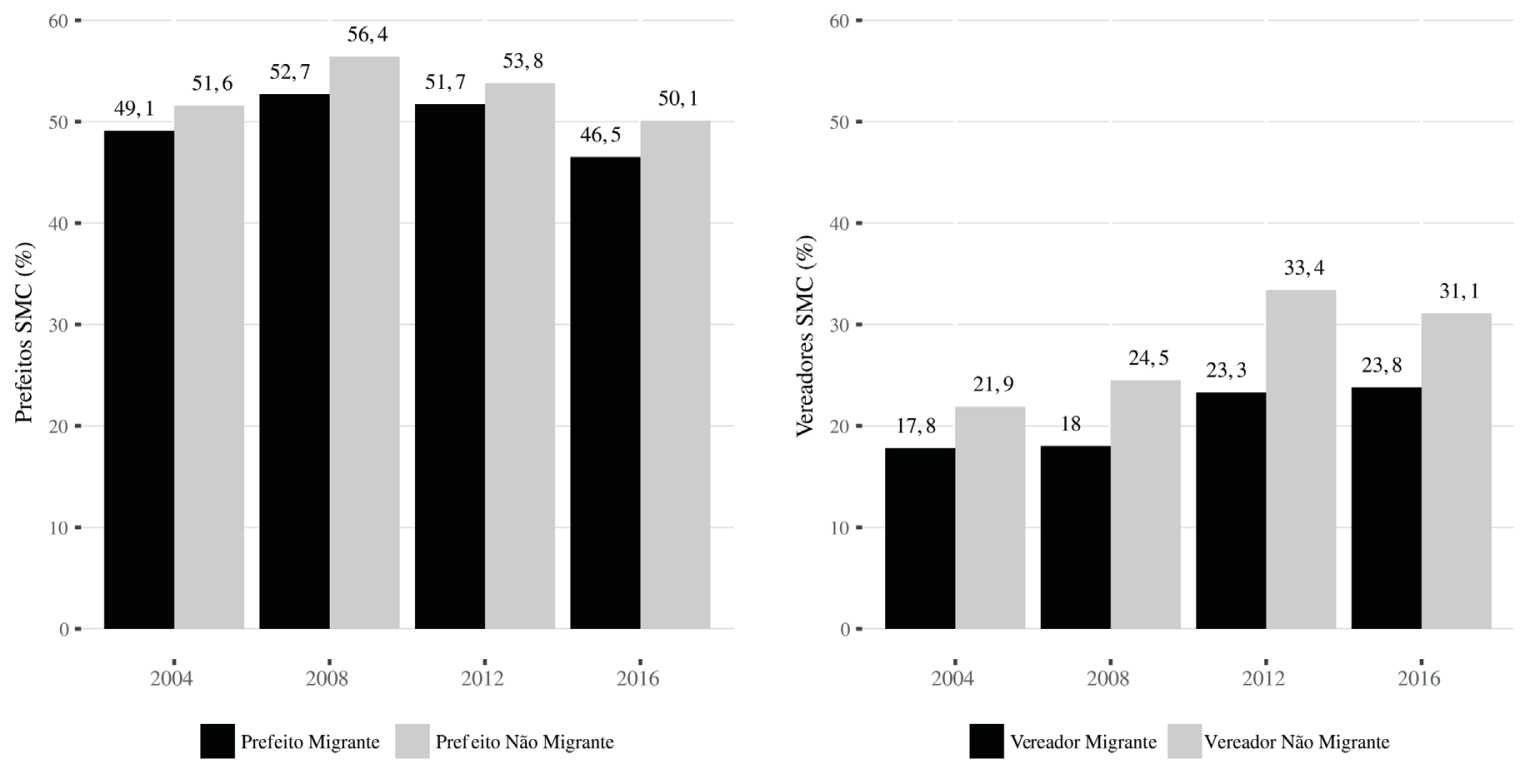

Fonte: Os autores, a partir de dados do Tribunal Superior Eleitoral. Disponível em: http://www.tse.jus.br/eleicoes/estatisticas/repositorio-de-dados-eleitorais-1/repositorio-de-dados-eleitorais. Acesso em: 15 jan. 2018.

que não migraram de partido. Em ambos os casos, estamos considerando apenas os candidatos sophomores que concorreram para o mesmo cargo (SMC) nas eleições consecutivas analisadas. Fizemos essa escolha pois queremos avaliar o impacto efetivo da migração sobre o sucesso eleitoral entre aqueles que possuem características similares. Concorrentes ao cargo de prefeito ou vereador que são SCD podem ter suas taxas de sucesso eleitoral para o cargo a que pretendem ampliadas ou diminuídas.

À primeira vista, o sucesso dos candidatos para o Executivo que migraram de partido é inferior ao daqueles que não mudaram de legenda. Nesse sentido, para a conquista das prefeituras, trocar de partido não representaria um acréscimo nas chances de vencer o pleito. No que concerne ao Legislativo, o padrão é ampliado: candidatos que não migram tiveram mais chances de ser eleitos dos que migraram.

No entanto, entre o número de candidatos não migrantes é possível pensar que uma parte significativa seja composta por lideranças partidárias consolidadas e identificadas com o partido. Tal realidade enviesaria as taxas de sucesso eleitoral a favor dos não migrantes, uma vez que essas lideranças tenderiam a ter maiores condições de serem eleitos do que lideranças novas. Buscamos controlar os efeitos das lideranças consolidadas sobre a taxa de sucesso eleitoral, comparando as taxas de sucesso entre migrantes e não migrantes que eram freshman na primeira eleição de cada par analisado (FEA). Por exemplo, na eleição de 2008 verificamos as taxas de sucesso eleitoral entre migrantes e não migrantes apenas dos candidatos que na eleição de 2004 eram freshman, ou seja, que tinham entrado na disputa naquele ano e não estavam na eleição de 2000. Com esse método, como não temos os dados das eleições de 1996, não conseguimos saber quem em 2000 era um candidato freshman, e, por consequência, não conseguimos comparar as taxas de sucesso eleitoral dos candidatos em 2004. Por outro lado, conseguimos analisar os resultados nas eleições de 20082012 e 2016. Paralelamente, também decidimos analisar as taxas de sucesso segundo a migração de FEA entre aqueles que foram eleitos e não eleitos no primeiro par de cada eleição consecutiva, visando ao máximo elimi- 
Gráfico 4 - Taxas de sucesso eleitoral entre freshman em eleição anterior, por cargo e eleição, no primeiro par
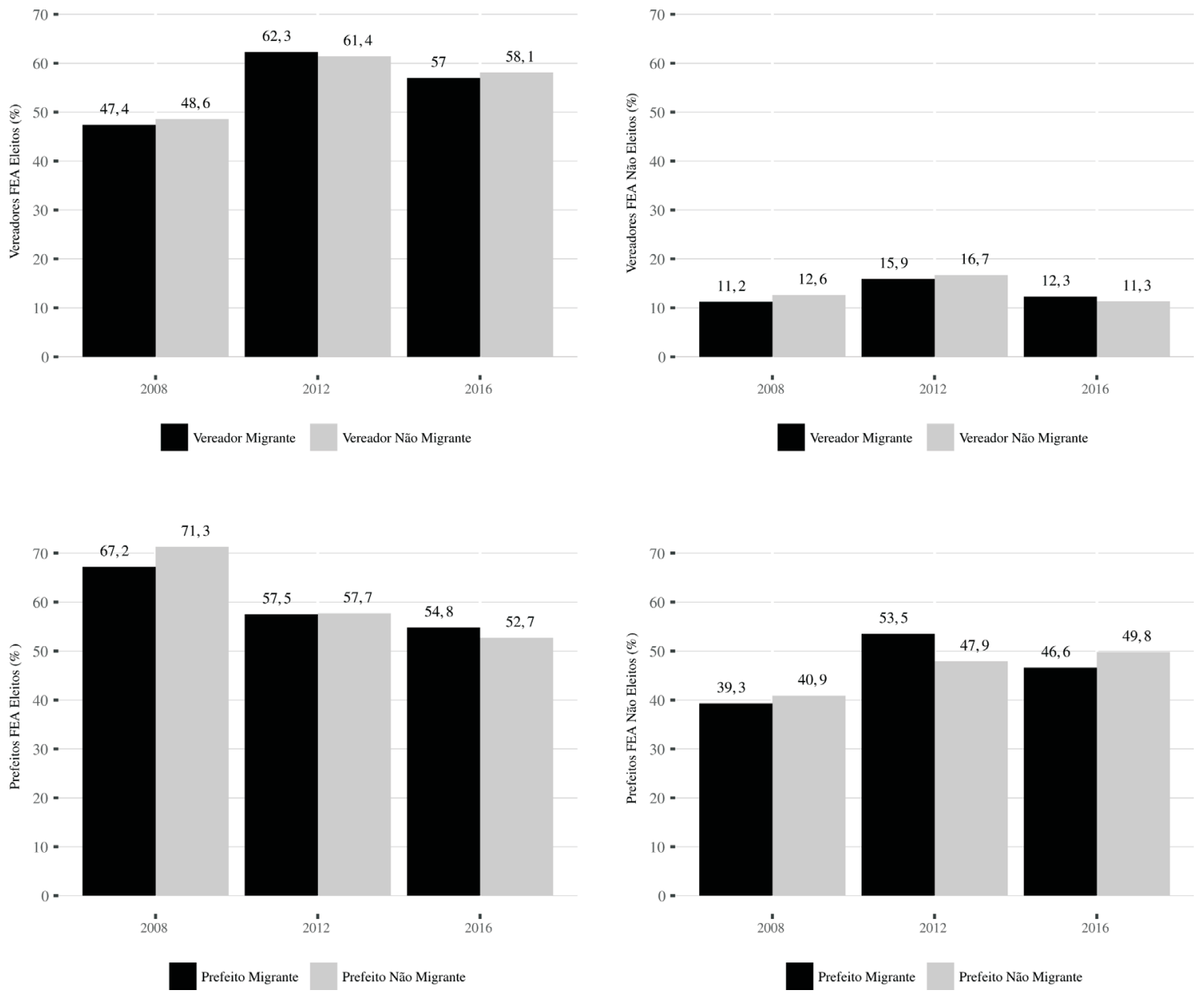

Fonte: Os autores, a partir de dados do Tribunal Superior Eleitoral. Disponível em: http://www.tse.jus.br/eleicoes/estatisticas/repositorio-de-dados-eleitorais-1/repositorio-de-dados-eleitorais. Acesso em: 15 jan. 2018.

nar qualquer tipo de viés que os dados possam conter. O Gráfico 4 descreve os resultados a partir dos controles discutidos neste parágrafo.

Os dados evidenciam que, quando controlamos os efeitos das lideranças sobre o sucesso, o efeito da migração sobre elas é indiferente. Não há uma tendência indicando que migrantes ou não migrantes possuem maiores ou menores taxas de sucesso eleitoral. Podemos inferir que, de maneira geral, para candidatos com pouco capital político e iniciantes na carreira, a decisão de permanecer em um partido não confere vantagem nem desvantagem competitiva em relação aos candidatos freshman que decidem migrar. Nossa hipótese é que, dado o baixo capital político, a relação de identificação desses candidatos com seus partidos tende a ser baixa, conferindo aos estreantes a possibilidade de migrar sem que sejam penalizados em termos de recursos ou perda de identidade; ao mesmo tempo, admitindo que a decisão de migrar decorre de uma estratégia do candidato de maximização do seu capital político, a entrada em um novo partido não se configura como um fator decisivo para a conquista de um cargo político. A efetividade eleitoral da migração entre candidatos para cargos municipais tende a estar atrelada a outras variáveis, tais como circunstância de campanha, capital político inicial e qualidade da organização partidária do partido do migrante. 


\section{Realidades regionais e migração partidária local}

Abordando a questão das migrações a partir da ótica das regiões do país, a Figura 1 demonstra que as tendências de migrações dos partidos e das candidaturas não são homogêneas em todo o território brasileiro, como já constatou Freitas (2008). Optamos aqui por mostrar as taxas de migração entre eleitos, uma vez que ela apresenta correlação com o número de candidaturas lançadas, elimina o viés do lançamento de candidatos para vereador e está atrelada diretamente à esfera da representação efetiva.

Em linhas gerais, os estados do Rio Grande do Sul e Santa Catarina apresentam as menores taxas médias de migração, tanto entre prefeitos e vereadores. E para cada eleição analisada entre 2004 e 2016, esses dois Estados contribuíram sempre com as menores taxas de migração. A região Sul, especialmente esses dois estados, se destaca como aquela onde ocorre o menor volume de trocas partidárias, assim como no plano nacional (Freitas 2008). Ao mesmo tempo, cada unidade da federação apresenta valores mais ou menos homogêneos ao longo do tempo, fazendo com que a ordem entre as menores e maiores taxas de cada estado se mantenham nas mesmas posições ao longo do tempo. Não encontramos uma relação significativa entre taxas de migração e número de sophomores por estado, nem há relação com o número de candidatos freshman. Ou seja, as taxas de migração não correspondem a uma maior ou menor rigidez do sistema partidário estadual em receber novos candidatos.

Nossa hipótese explicativa é que existem dois efeitos incidindo sobre as taxas de migração no país. A primeira é de ordem geral e formal, e resulta de limitações às regras de fidelidade partidária, a exemplo da Resolução 22.526/07

do TSE. A segunda diz respeito às características do jogo político estadual, se estabelecendo pelo efeito da competição partidária e dos tipos de partidos que se estabelecem em cada estado, como propôs Lima Júnior $(1993$; 1997) a partir da ideia das lógicas políticas contextuais. Para verificarmos essa hipótese, traçamos uma associação entre as taxas de migração e a concentração partidária em cada estado. Utilizamos, novamente, o índice de Gini sobre a oferta de candidatos por partido, em cada estado. Assim, temos uma medida que nos indica qual o nível da concentração partidária no lançamento de vereadores e prefeitos. Hipoteticamente, o índice Gini igual a 1 indicaria que um partido qualquer concentra $100 \%$ das candidaturas no estado, e um Gini igual a 0, que todos os partidos do espectro político nacional lançam igualmente o mesmo número de candidatos naquele estado (Figura 1).

O Gráfico 5 comprova nossa hipótese. Há uma relação negativa entre concentração partidária e taxa de migração nos estados, seja para prefeito, seja para vereador. Ou seja, quanto menor o número de partidos competindo no jogo político de cada estado, menores são as oportunidades que se abrem aos candidatos para migrarem de partido. Rio Grande do Sul e Santa Catarina apresentam as menores taxas de migração exatamente por serem os estados onde há uma maior concentração partidária na oferta de candidaturas a prefeito e vereador entre os anos de 2004 e 2016. No Rio Grande do Sul, o índice Gini é de 0,82 para prefeito e 0,75 para vereador; em Santa Catarina, 0,81 e 0,74, respectivamente.

Estados do Nordeste, Norte e o Rio de Janeiro, por outro lado, apresentam as menores concentrações, com maior número de migração. No entanto, não apenas a competição é importante para a variação das taxas de migração, mas também a maneira como os partidos estão organizados e competem em cada estado acaba por influenciar este fenômeno.

Essas evidências impõem alguns problemas para a verificação do papel do desenvolvimento sobre as taxas de migração. Dado que a concentração de 
cidades pobres tende a se localizar nas regiões Norte e Nordeste, uma análise que verifique a relação entre desenvolvimento social e migração deve ser feita levando-se em conta o papel dessa distribuição. Por outro lado, a variável concentração da oferta partidária, que pode ser entendida como uma proxy de organização partidária, pode também ser afetada pelas condições socioeconômicas dos municípios. Uma hipótese é que nos municípios mais pobres seja

Figura 1 - Porcentagem média damigração de candidatos a prefeito e vereador eleitos, por estado (Brasil 2004-2016)

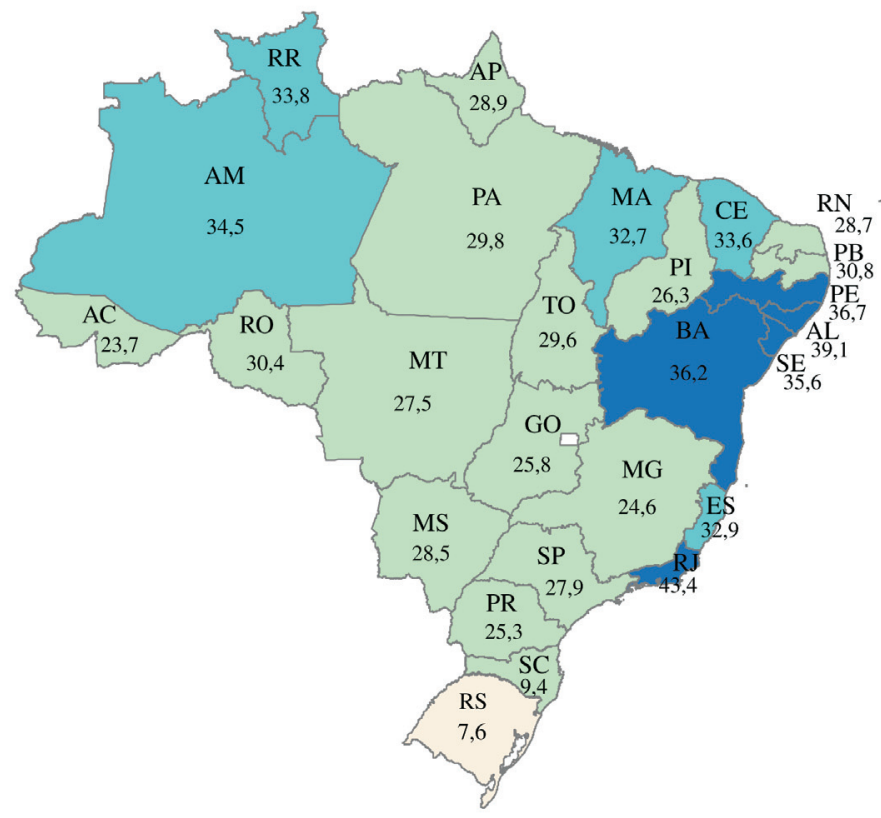

Migração Vereadores Eleitos
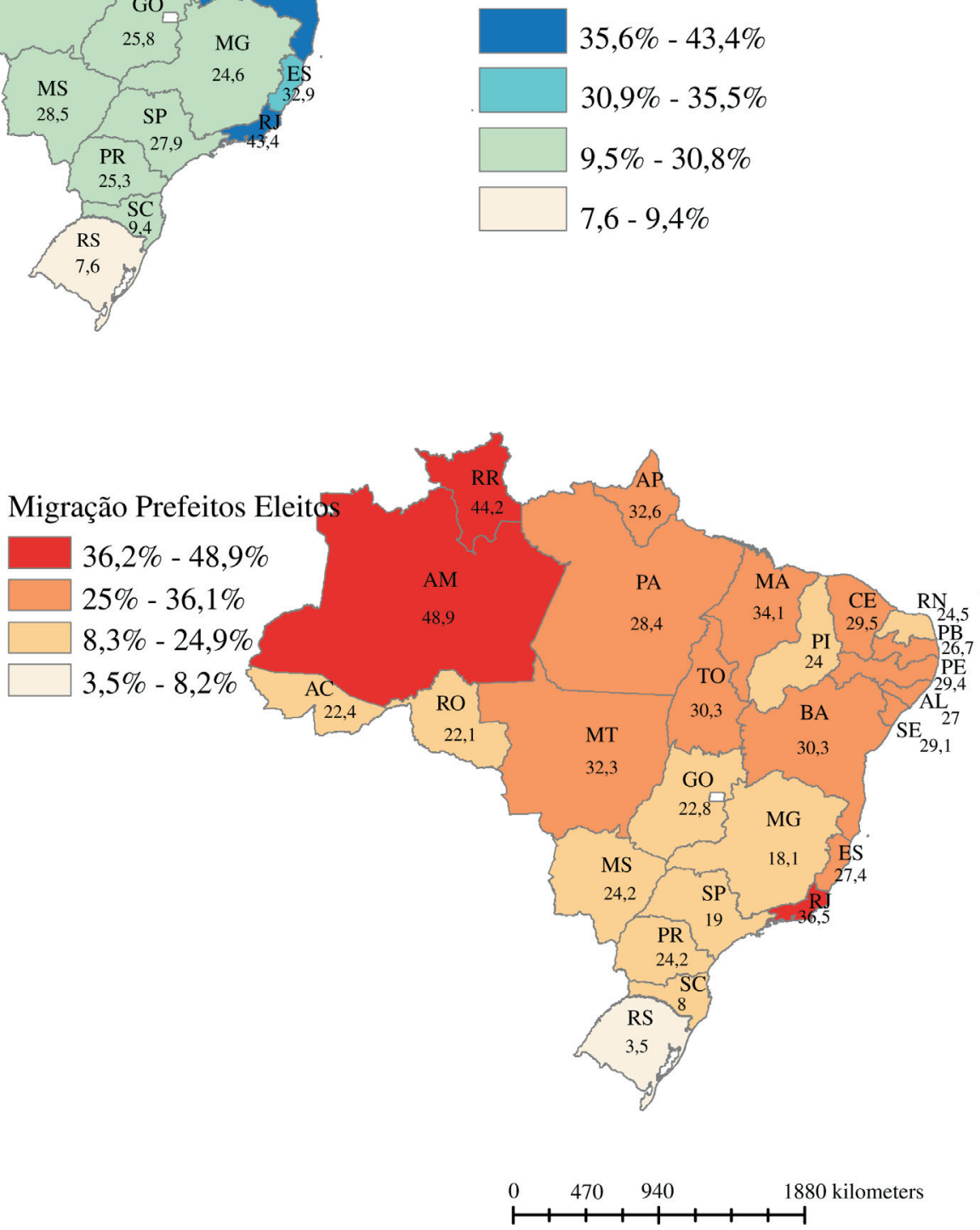

Fonte: Os autores, a partir de dados do Tribunal Superior Eleitoral. Disponível em: http://www.tse.jus.br/eleicoes/estatisticas/repositorio-de-dados-eleitorais-1/repositorio-de-dados-eleitorais. Acesso em: 15 jan. 2018. 
Gráfico 5 - Taxa de migração por concentração partidária nos Estados (vereadores e prefeitos 2000-2016)

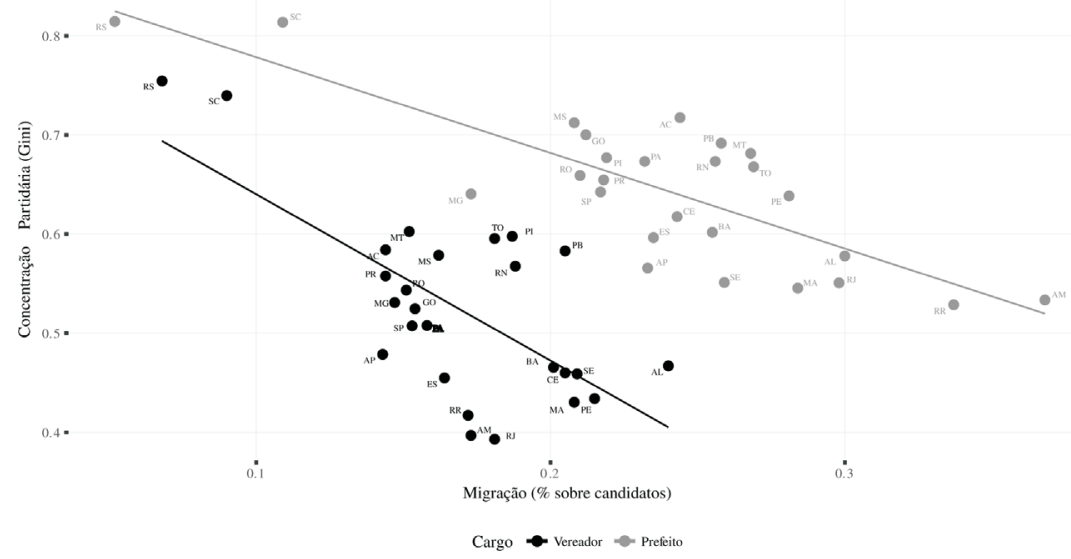

Fonte: Os autores, a partir de dados do Tribunal Superior Eleitoral. Disponível em: http://www.tse.jus.br/eleicoes/estatisticas/repositorio-de-dados-eleitorais-1/repositorio-de-dados-eleitorais. Acesso em: 15 jan. 2018.

mais difícil estabelecer uma organização partidária coesa, uma vez que estes municípios seriam mais vulneráveis a práticas políticas do tipo clientelista.

Para verificar a relação entre desenvolvimento econômico e migração, definimos amostras estratificadas de acordo com a região, categorias de concentração partidária (Alta, Média e Baixa) e categoria de PIB per capita (Ricos, Médios e Pobres). No total, 45 estratos foram identificados, e selecionamos, aleatoriamente, mil casos da base de vereadores que mantinham o mesmo número de casos para cada estrato definido. Em seguida, analisamos a proporção de vereadores migrantes, não migrantes e candidatos freshman dessa amostra, segmentado pelas categorias de PIB per capita definidos. Repetimos essa análise 5.000 vezes, de forma a termos 5.000 amostras distintas com 1.000 casos cada. O Gráfico 6 mostra o histograma de densidade do percentual de vereadores migrantes para cada uma das 5.000 amostras.

Podemos perceber pelo Gráfico 6 que, mesmo controlando a amostra por estratos de região, concentração da oferta de candidatos e faixas de PIB per

Gráfico 6 - Histograma de densidade do percentual de vereadores migrantes por categorias de PIB per capita

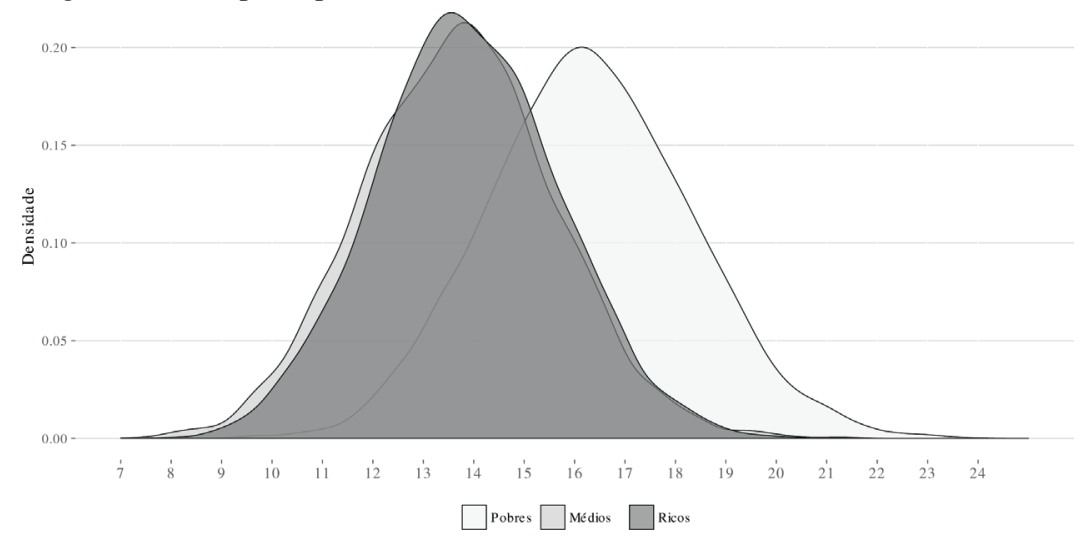

Fonte: Os autores, a partir de dados do Tribunal Superior Eleitoral. Disponível em: http://www.tse.jus.br/eleicoes/estatisticas/repositorio-de-dados-eleitorais-1/repositorio-de-dados-eleitorais. Acesso em: 15 jan. 2018. 
capita, os municípios com menor PIB per capita tendem a apresentar um número maior de vereadores migrantes do que nos municípios médios e ricos. $88,3 \%$ das amostras de municípios com PIB per capita pobre possuíam um percentual de vereadores migrantes maior que a média do percentual de migrantes das amostras de municípios ricos. Há evidências, portanto, de que existe um efeito positivo do desenvolvimento dos municípios sobre a organização partidária.

\section{Os partidos e a migração partidária local}

9 Figueiredo e Limongi (1995), por exemplo, utilizaram o critério das votações em plenário para separar os partidos ideologicamente.
Ao falarmos sobre as agremiações especificamente, observamos diferentes padrões de comportamento, a depender do bloco ideológico. Sabemos que essas divisões dos partidos são polêmicas e, muitas vezes, insuficientes (Miguel 2010). Todavia, o elemento ideológico pode ajudar tanto na compreensão do sistema político-partidário (Singer 2002) quanto nas análises sobre a atuação e a organização dos partidos. As afinidades ideológicas dos partidos ${ }^{9}$ são ferramentas capazes de distribuir os partidos ao longo de uma escala esquerda-direita (Figueiredo \& Limongi 1995; Melo 2004). No Gráfico 7, analisamos as taxas de preservação de candidatos que cada partido mantém entre dois pares de eleição. Cada ponto do boxplot representa a porcentagem de candidatos que decidiu se candidatar novamente (no segundo par de cada eleição) sem migrar de partido, sobre o total de candidaturas que o partido lançou no primeiro par de eleição.

Gráfico 7 - Preservação dos quadros partidários, por partido e bloco ideológico (vereador e prefeito 2004-2016)
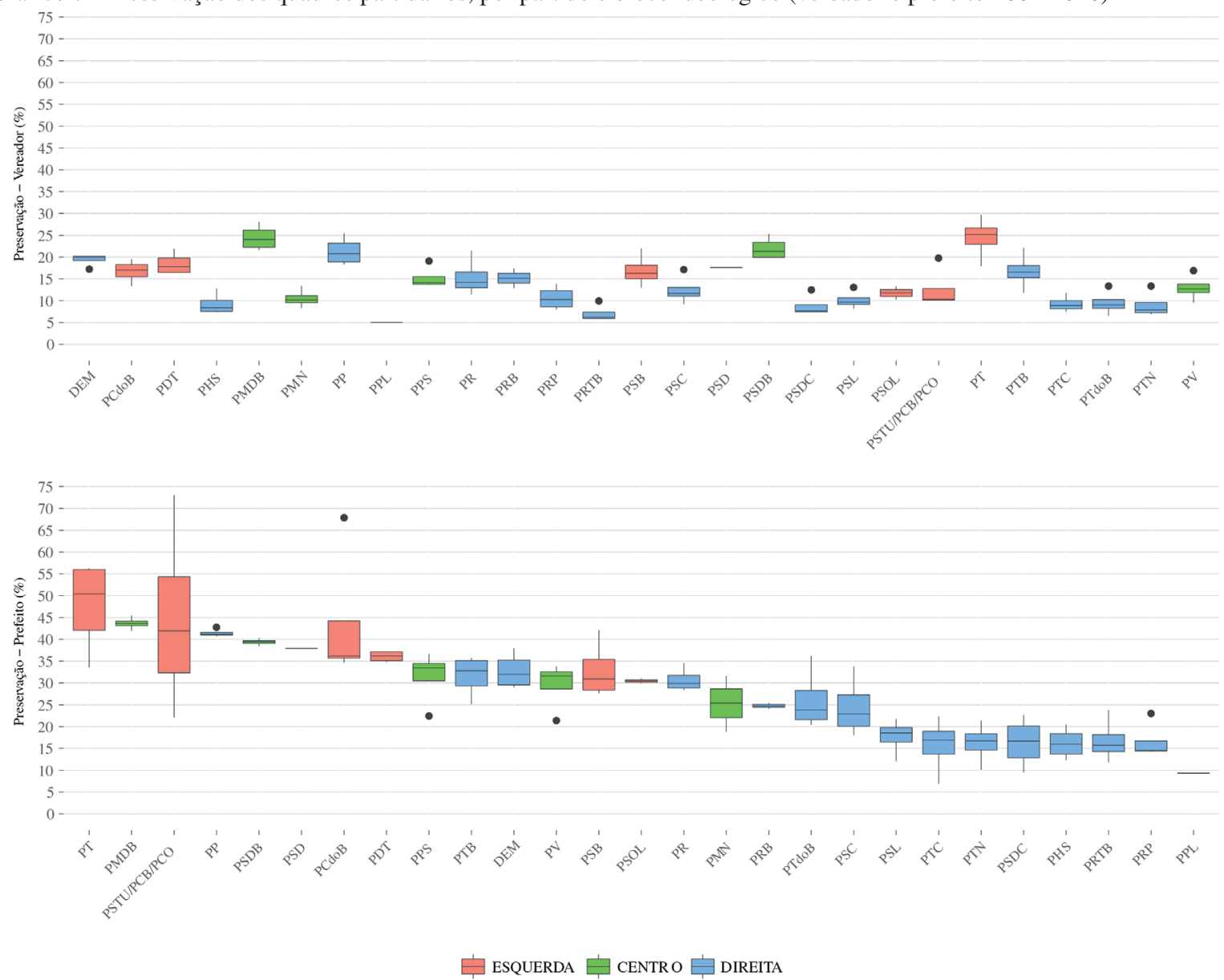

Fonte: Os autores, a partir de dados do Tribunal Superior Eleitoral. Disponível em: http://www.tse.jus.br/eleicoes/estatisticas/repositorio-de-dados-eleitorais-1/repositorio-de-dados-eleitorais. Acesso em: 15 jan. 2018. 
${ }^{10}$ Total de candidatos nos três ciclos eleitorais: PSTU -90 , 73 e $54 ; \mathrm{PCO}-44,8$ e 7 ; PSOL - 271 e 639 (2008 e 2012, respectivamente).
Assim, por exemplo, o PPL que participou apenas de um par de eleição (2012-2016) conseguiu manter 93 candidatos a vereador, em 2016, concorrendo pelo mesmo partido, de um total de 1.846 candidaturas lançadas para vereador em 2012. Ou seja, o partido conseguiu preservar apenas $5 \%$ do total de candidaturas a vereador que tinha nas mãos em 2012.

Como era esperado, podemos perceber que as taxas de preservação entre prefeitos e vereadores são diferentes. Dada as características do sistema eleitoral e a relativa importância do Executivo frente ao Legislativo em termos eleitorais, as taxas de preservação de prefeitos tendem a ser maiores do que de vereadores. Também é possível notar que PT, PMDB, PP e PSDB conseguem ter as maiores taxas de preservação; do outro lado, entre as menores taxas, há um predomínio dos pequenos partidos de direita. Tal característica é resultado da capacidade organizativa desses partidos de angariar quadros e preservar candidatos ao longo do tempo.

Quanto ao espectro ideológico, podemos notar alguns padrões que foram também detectados pela literatura corrente (ver Gráfico 7). Em média, os partidos de esquerda conseguem ter as melhores taxas de preservação de candidatos de um pleito para o outro (média de 16,7\% entre vereadores e 38,7\% entre prefeitos). Esta tendência já era observada no plano nacional: Nicolau (1996) constata que partidos de esquerda mostram as menores proporções de deputados migrantes e Melo (2004) corrobora este achado. Para o nível local, o PT tende a ser o partido mais bem sucedido na estratégia de preservação de todo o sistema partidário.

Também é possível notar que mesmo os partidos pequenos de esquerda, como o PSOL, PSTU, PCO e PCB tendem a ter taxas de preservação maiores que os menores partidos de direita. Ainda que, em números absolutos, esses partidos apresentem poucos candidatos ao longo da série histórica e, juntamente ao PSOL, são os partidos que menos lançam candidatos ${ }^{10}$, é importante frisar a capacidade de retenção de seus quadros - o que, em muito, se associa aos vínculos fortes que partidos de esquerda, em geral, tendem a manter com suas lideranças (Gráfico 7).

Quando agregamos os partidos ideologicamente, notamos que no plano local a direita se mostra mais volátil e dispersa, como indicam Mainwaring, Meneguello e Power (2000), no que se refere à organização interna e à atuação política dessas legendas em âmbito nacional. A direita brasileira, desde o contexto da redemocratização, é marcada pela alta fragmentação e pela dificuldade, consequentemente, de se articular em torno de poucas (porém representativas) agremiações (Mainwaring, Meneguello \& Power 2000). Para a Câmara Federal, Melo (2004, p. 109) observa que:

à exceção do PFL, nenhum outro partido firmou-se como referência para a massa de deputados que se posiciona à direita no espectro ideológico brasileiro. Evidentemente, pode-se fazer referência ao reduzido núcleo dirigente do PPB [atual PP], ou a um ou outro congressista histórico do PTB. Mas, para além desses limites, os vínculos entre os deputados e os seus partidos mostraram-se extremamente tênues.

Dentre as legendas de direita, destacam-se principalmente o PFL/DEM, o PDS/PP e o PTB, todos partidos com trajetórias históricas longas no sistema partidário brasileiro, remontando ao período de abertura política (Kinzo 1993). O PFL/DEM foi destacado por Melo (2004) como o único partido de direita capaz de evitar um número significativo de deserções na Câmara dos Deputados (a taxa de deserção, no início dos anos 2000, era de $23 \%$ em média). De fato, para o nível local, o partido consegue manter o destaque no interior do bloco da direita, ao registrar uma taxa média de $66,4 \%$ de manutenção de seus candidatos às prefeituras e às câmaras. PP e PTB também apresentam porcentagens 
consideráveis, indicando que se tratam de duas agremiações com presença organizativa nos municípios, conforme já demonstrado por Braga, RodriguesSilveira e Borges ${ }^{11}$ (2012) (Gráfico 8).

Gráfico 8 - Preservação dos quadros partidários, por bloco ideológico (vereador e prefeito 2004-2016)
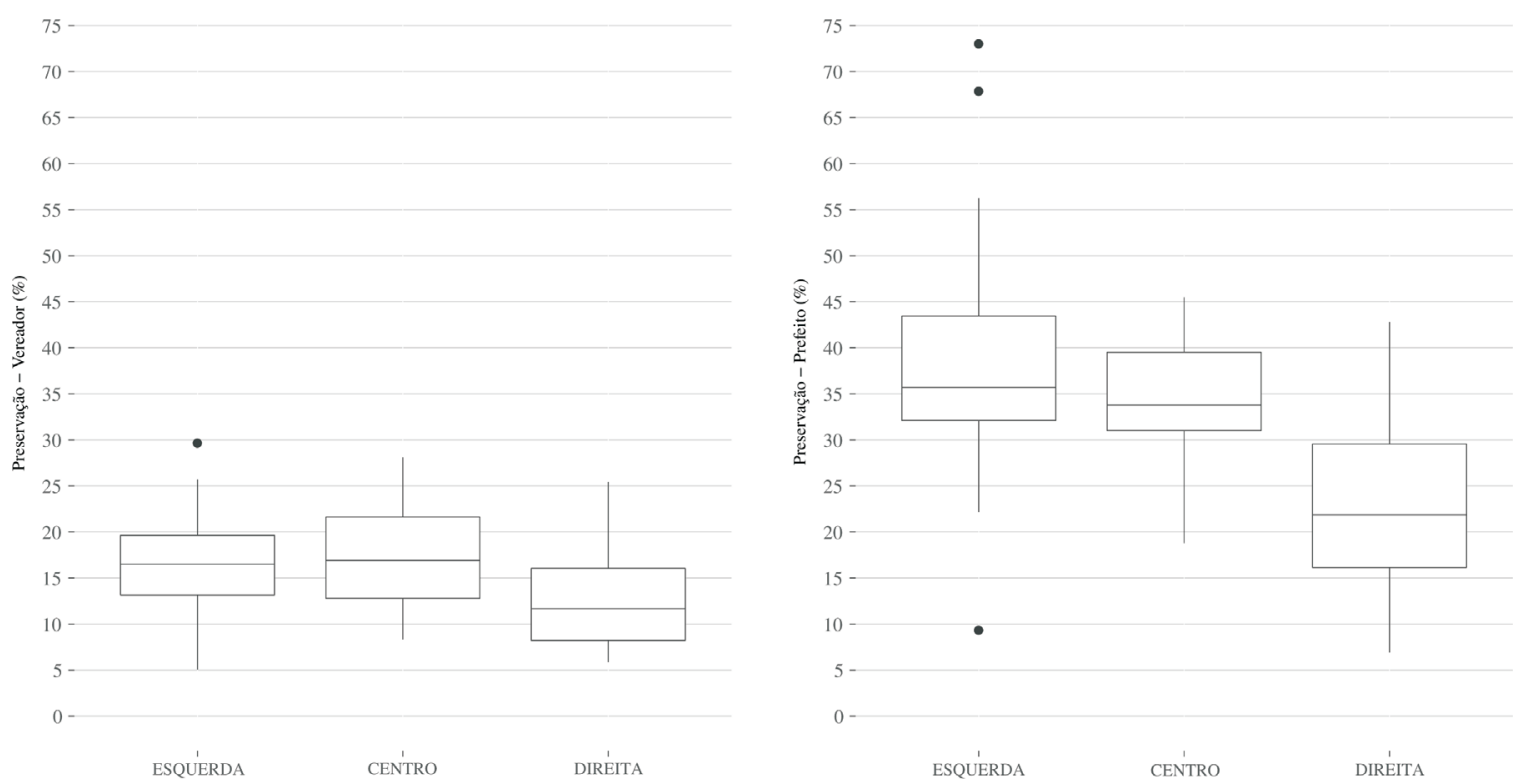

Fonte: Os autores, a partir de dados do Tribunal Superior Eleitoral. Disponível em: http://www.tse.jus.br/eleicoes/estatisticas/repositorio-de-dados-eleitorais-1/repositorio-de-dados-eleitorais. Acesso em: 15 jan. 2018.

Gráfico 9 - Rede de migração partidária entre vereadores e prefeitos eleitos antes de migrar (Brasil 2004-2016)

Vereadores Eleitos

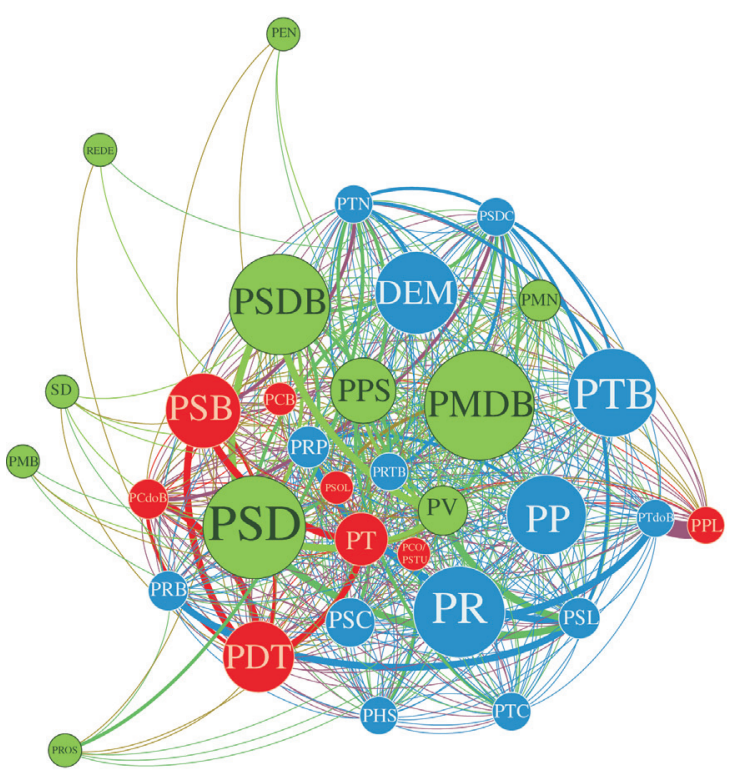

\section{Prefeitos Eleitos}

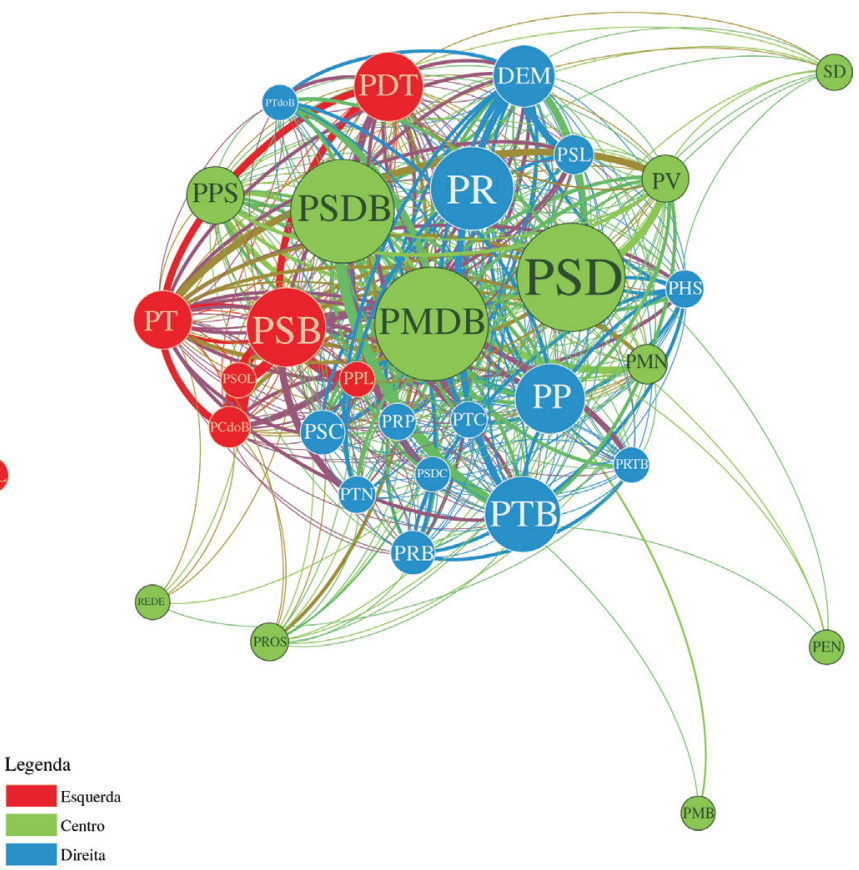

Fonte: Os autores, a partir de dados do Tribunal Superior Eleitoral. Disponível em: http://www.tse.jus.br/eleicoes/estatisticas/repositorio-de-dados-eleitorais-1/repositorio-de-dados-eleitorais. Acesso em: 15 jan. 2018. 
11 De acordo com os autores, PP, PTB e DEM se encontravam presentes em mais de $80 \%$ dos municípios brasileiros, em 2011 (Braga, Rodrigues-Silveira \& Borges 2012, p.33).
Com os dados que captamos, podemos ter uma visão geral sobre o sentido das migrações e suas tendências. O Gráfico 9 apresenta dois gráficos de rede, representando o sentido de cada migração partidária dos vereadores e prefeitos eleitos no primeiro par de cada eleição municipal analisada. Ou seja, entre aqueles que foram eleitos e decidiram migrar em algum momento do mandato concorrendo por outro partido na eleição seguinte. Com isso, podemos analisar o impacto das migrações sobre a representação.

Os gráficos de rede são compostos por nós (cada círculo do Gráfico 9) e arestas (as linhas ligando os nós). O primeiro identifica os partidos e o segundo, a ligação de saída ou entrada entre os nós (partidos). Para uma interpretação correta dos gráficos precisamos levar em conta quatro dimensões:

1) Diâmetro dos nós: indicam a quantidade de candidatos que em todo o período analisado migraram para o partido em questão (graus de entrada). Por exemplo, no primeiro elemento do Gráfico 9, o PMDB apresenta o maior nó de todos os partidos, pois do total de 31.319 migrações de vereadores eleitos analisadas, em torno de $11 \%$ tiveram como direção o PMDB;

2) Espessura das arestas: corresponde ao percentual de candidatos de cada partido que migrou para outro (peso das arestas). Por exemplo, dos 86 candidatos eleitos a prefeito do PV que migraram, $14 \%$ tiveram como destino o PSD. A espessura da aresta que liga os nós PV e PSD, nesta mesma direção, corresponde a esse percentual.

3) Cor das arestas e dos nós: diferenciamos os nós partidários pela ideologia a que pertencem. Assim, os partidos de esquerda estão representados pela cor vermelha, os de direita pelo azul e o centro pelo verde. As cores das arestas representam uma combinação de cores pela ligação entre as cores dos partidos de saída e entrada. Por exemplo, uma aresta (seja de saída, seja de entrada) ligando DEM e PT tende a ter uma cor roxa, resultante da mistura entre o azul (direita, DEM) e o vermelho (esquerda, PT). Por consequência, as arestas entre partidos da mesma ideologia são representadas pelas cores de cada ideologia.

4) Posição dos nós e estrutura da rede: utilizamos o algoritmo Force Atlas 2 (Jacomy et al., 2014) do aplicativo Gephi 0.82 para estruturar nossa rede. Esse algoritmo permite um desenho da rede que se orienta por um processo simultâneo de aproximação entre as arestas e repulsão dos nós. Este processo é orientado a partir dos graus de entrada e saída de cada nó, na repulsão (o número de migrantes entre os partidos) e do peso das arestas, na atração. O resultado final é o desenho de uma rede onde os nós com maior afinidade, ou seja, com mais graus de entrada e saída entre eles, pelo efeito de atração das arestas, tendem a permanecer próximos uns dos outros. Ao mesmo tempo, o processo de repulsão dos nós, faz com que a rede se expanda ou diminua permitindo a conformação visual de clusters.

Para se ter uma ideia de como o algoritmo detecta e representa a formação dos clusters, simulamos uma distribuição ideal de migrações a partir do número efetivo (dados reais) de candidatos a vereador eleitos. Nesta simulação, estabelecemos que a probabilidade de um candidato de um partido de um bloco ideológico definido migrar para o mesmo bloco fosse de $80 \%$, definindo assim clusters claros entre os blocos. Se este bloco fosse de esquerda, definimos uma chance de $5 \%$ de o candidato ir para a direita e $15 \%$ para o centro. Se fosse de direita, ao contrário, $5 \%$ foi a chance de ir para a esquerda. Caso fosse de centro, definimos $10 \%$ de chance de o candidato ir tanto para a esquerda como para a direita. Em seguida, distribuímos os candidatos segundo a porcentagem efetiva 
que cada partido apresentou. Assim, em nossa simulação, um candidato qualquer que saiu de um partido de esquerda teria $80 \%$ de chance de ir para um partido do mesmo bloco ideológico e, uma vez definido, $38 \%$ de chance de ir para o PSB, dado que entre as migrações efetivas analisadas, $38 \%$ dos candidatos que foram para algum partido de esquerda tiveram como destino o PSB. Com os dados simulados para os 31.319 candidatos efetivos, plotamos o Gráfico 10 .

Analisando o Gráfico 9 em comparação com o gráfico idealizado (Gráfico 10), podemos concluir, de maneira geral, que não há uma conformação clara de clusters entre os blocos ideológicos para vereador. Entre prefeitos, por sua vez, foi possível detectar um pequeno bloco de esquerda, que tem no PSB o representante com maior nó, e um bloco de direita tendo o PTB como o partido que mais recebeu candidatos. Ou seja, a dimensão ideológica tem um peso maior na decisão de migrar entre os candidatos ao Executivo do que no Legislativo. No entanto, ainda comparando com o gráfico esperado (Gráfico 10), notamos que, em ambos os casos, não há uma separação nítida entre blocos. Todos os partidos tendem a convergir ao centro ao mesmo tempo, formando um grande círculo, o que indica que há uma intensa troca de candidatos entre todos os partidos do sistema em âmbito municipal.

PMDB, PSDB e PSD, tanto para vereador quanto para prefeito, tendem a possuir grande força de atração, apresentando os maiores nós e com tendência a permanecerem mais ao centro da rede e ligando-se a quase todos os partidos. Ou seja, são agremiações que recebem e provêm candidatos para todos os partidos, ao mesmo tempo em que congregam um número grande de migrações entre os

Gráfico 10 - Simulação de uma rede de migração de vereadores (com atração de $80 \%$ entre os blocos)

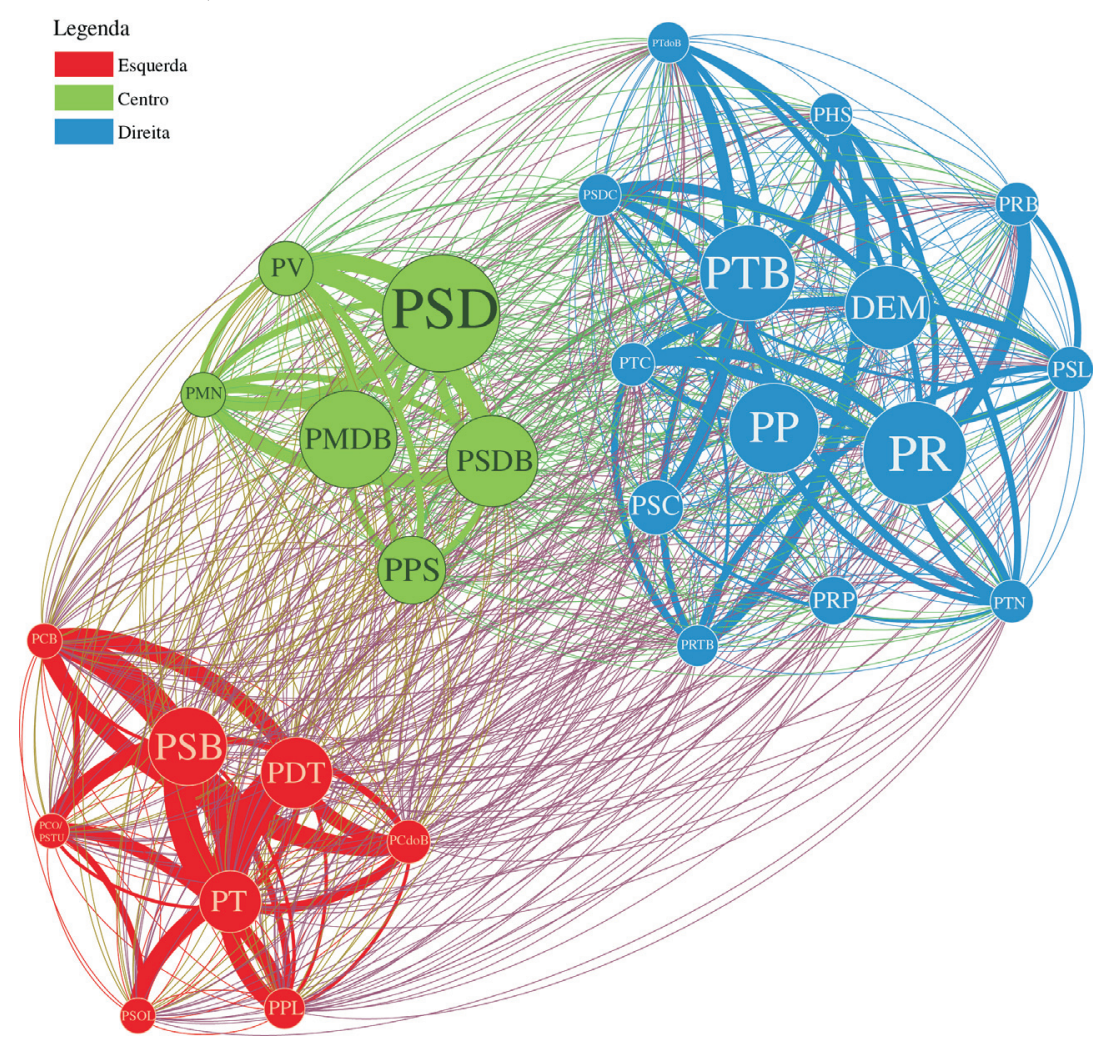

Fonte: Os autores, a partir de dados do Tribunal Superior Eleitoral. Disponível em: http://www.tse.jus.br/eleicoes/estatisticas/repositorio-de-dados-eleitorais-1/repositorio-de-dados-eleitorais. Acesso em: 15 jan. 2018. 
três. Os partidos de esquerda possuem nós menores, indicando que tendem a migrar menos. PSOL e PCdoB tendem a se aproximar de PT e PSB, indicando uma preferência na troca entre esses partidos. O PDT, por sua vez, tende a ter uma dinâmica de migração mais próxima a partidos de direita e de centro do que de esquerda. Entre os partidos de direita PR, PP, PTB e DEM apresentam os maiores nós.

Por fim, partidos como REDE, SD, PROS, PMB e PEN foram posicionados nas áreas periféricas da rede, formando pontas. Isso se deve ao fato de que esses partidos estrearam nas eleições municipais em 2016. Com isso somente foi possível identificar os candidatos que migraram para estes partidos, não os que saíram. Ainda assim, é possível notar que a REDE, no caso da rede de migração de prefeitos, por exemplo, se posicionou próxima ao cluster da esquerda, indicando uma afinidade de troca de candidatos que saíram do PSOL e PCdoB e foram para a REDE. Os outros se situaram próximos ao cluster da direita, sendo que o partido SOLIDARIEDADE se encontra entre a conformação dos clusters de esquerda e direita formados no círculo. Pelas cores, é possível perceber a predominância do azul (direita) sobre o mapeamento das redes, mostrando o peso desses partidos para o processo de migração.

Gráfico 11 - Rede da migração partidária entre blocos ideológicos (vereadores eleitos) (Brasil 2004-2016)

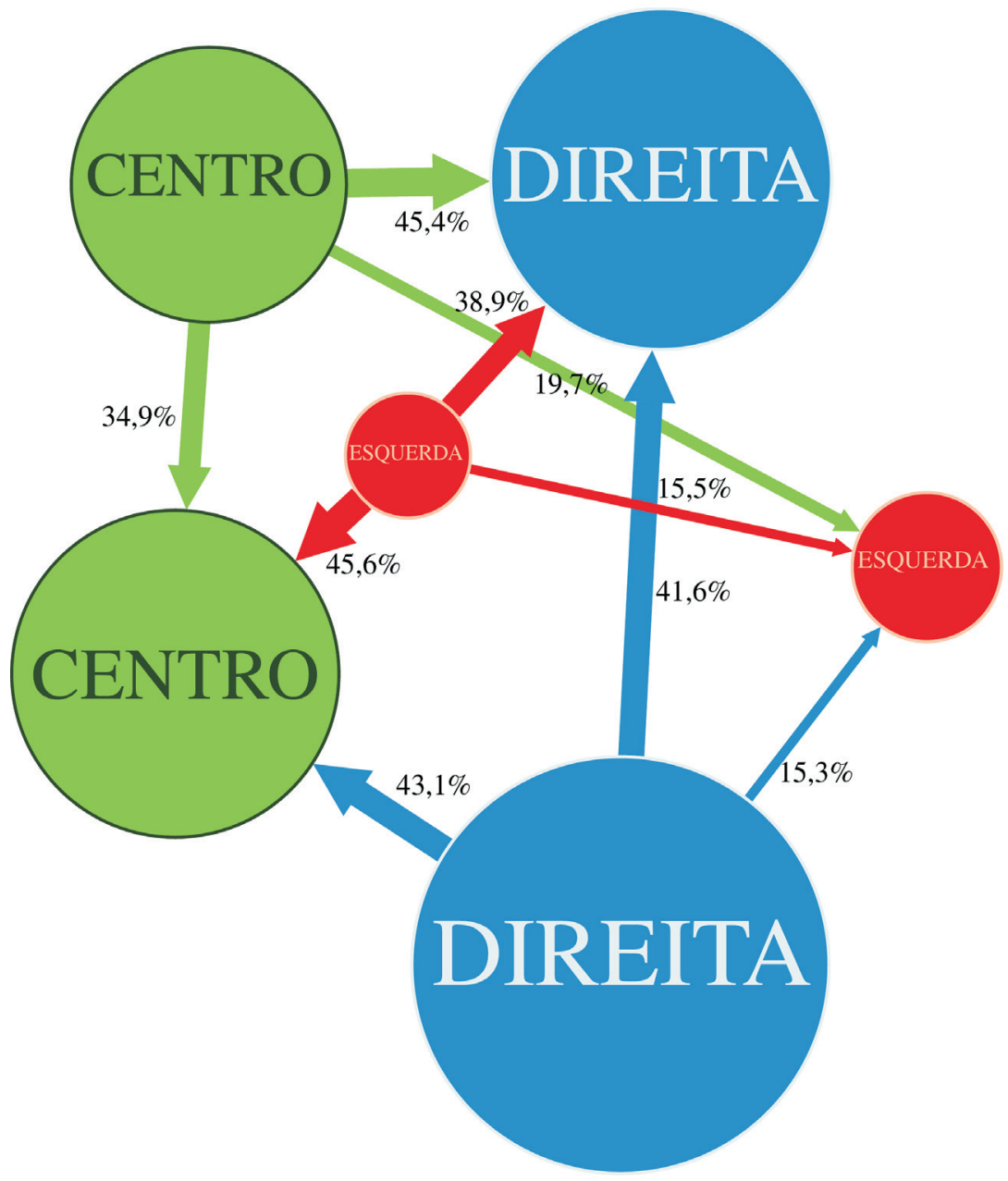

Fonte: Os autores, a partir de dados do Tribunal Superior Eleitoral. Disponível em: http://www.tse.jus.br/eleicoes/estatisticas/repositorio-de-dados-eleitorais-1/repositorio-de-dados-eleitorais. Acesso em: 15 jan. 2018. 
Gráfico 12 - Rede da migração partidária entre blocos ideológicos (prefeitos eleitos) (Brasil 2004-2016)

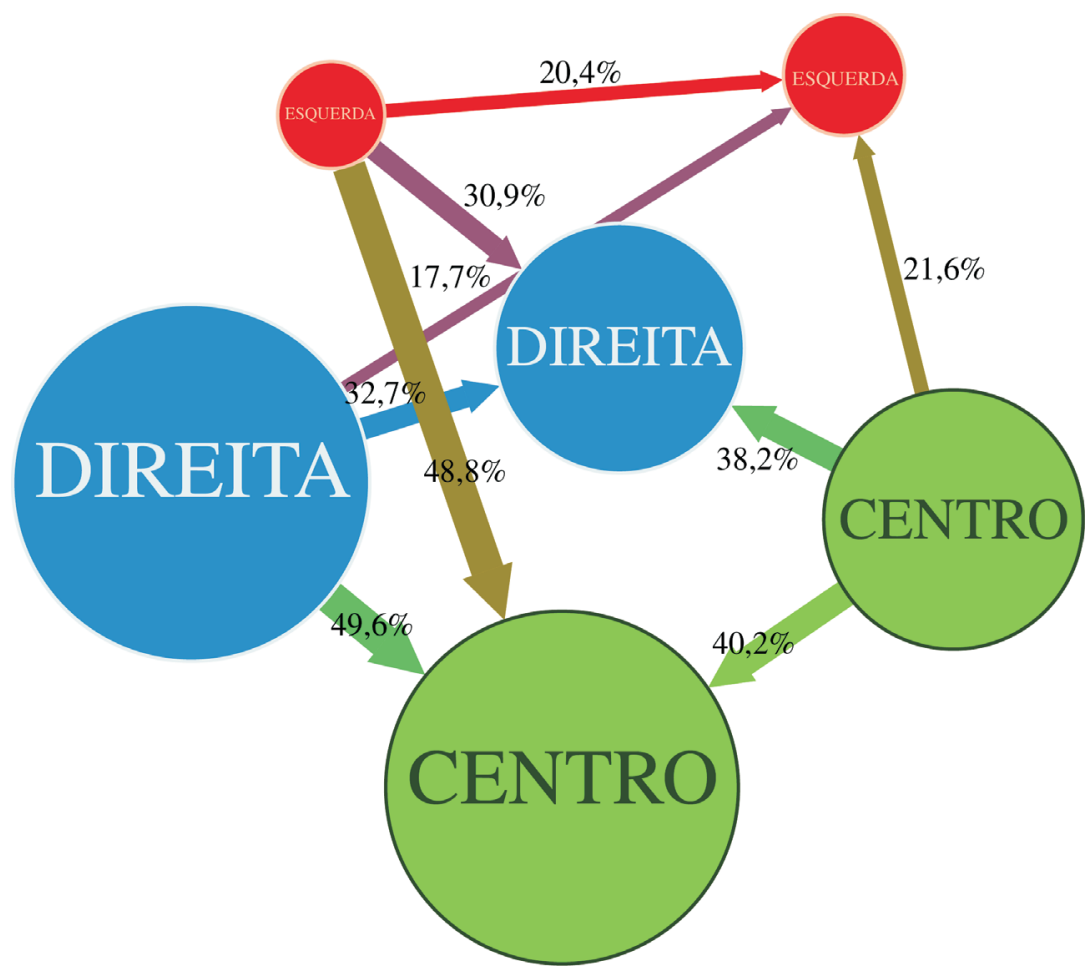

Fonte: Os autores, a partir de dados do Tribunal Superior Eleitoral. Disponível em: http://www.tse.jus.br/eleicoes/estatisticas/repositorio-de-dados-eleitorais-1/repositorio-de-dados-eleitorais. Acesso em: 15 jan. 2018.

Para entendermos melhor a relação da migração entre os campos ideológicos, agregamos os partidos dos candidatos eleitos entre os blocos correspondentes e plotamos um gráfico de rede (Gráfico 11 e Gráfico 12) simplificando a relação entre os blocos ideológicos. Nele, é possível perceber que a migração entre partidos do mesmo bloco tende a não ser predominante. Tanto esquerda quanto a direita (para vereador e prefeito) tendem a ir para os partidos do centro, especialmente para o PMDB, PSDB e PSD. Partidos de centro tendem a migrar para os partidos de direita ou a permanecerem. Ao contrário, é possível perceber uma menor mobilidade em direção aos partidos de esquerda.

\section{Conclusões: estratégias partidárias em nível local}

McElroy (2003) afirma que políticos, ao escolherem o grupo político (ou partido) para o qual pertencerão, levam em consideração os custos e os benefícios que serão obtidos, de acordo com determinada estratégia. Patronagem, influência nas tomadas de decisões, recursos eleitorais e ganhos ideológicos são alguns dos benefícios que podem ser obtidos, de acordo com o autor, contra custos - perda de cargos, credibilidade e base eleitoral, por exemplo. Nesse sentido, a troca de legenda não busca, unicamente, atender aos desejos individuais das lideranças. Ela perpassa por um cálculo anterior, que podemos chamar de critério partidário. A agremiação a ser escolhida importa, na medida em que ela poderá trazer mais ou menos benefícios ao político.

Melo argumenta nesse mesmo sentido: 
"Se a mudança de partido é entendida como estratégia de maximização, a lealdade à legenda de origem também pode ser (...) mais importante do que distinguir entre a permanência em um partido como fruto de um cálculo estratégico, ou como parte de um processo de identificação, é perceber que as duas situações tendem a ocorrer e contribuem para a criação e robustecimento dos vínculos entre deputado e partido. Quanto mais fortes eles forem, maior a possibilidade de o congressista permanecer em sua agremiação de origem" (Melo 2004, p.116).

Ou seja, as migrações partidárias se baseiam em lógicas que, em alguma medida, perpassam os partidos políticos - levam-se, em conta, o posicionamento dos indivíduos e, também, das legendas em si. Como sintetiza Freitas (2008, p.93), sobre o Legislativo federal, "diferenciar migrantes e não migrantes envolve, portanto, entender o que os parlamentares buscam através da filiação partidária, a relação entre os parlamentares e seus partidos, as características do partido de origem e destino, as características do eleitor e da disputa eleitoral no distrito do parlamentar".

Trazendo como nível de análise os municípios, procuramos explorar alguns destes aspectos, especialmente os posicionamentos das agremiações de origem e destino (através de suas ideologias), os padrões de migração observados pelas diferentes regiões do país e as relações entre partidos e candidatos a prefeito e a vereador. Nosso trabalho se orientou a partir de três eixos, ancorados em um diálogo com a literatura corrente sobre o tema nas outras arenas da política nacional: um eixo que versa sobre a constituição do jogo político nos municípios, determinado por uma análise sobre o impacto da migração no sucesso eleitoral dos candidatos e o efeito do desenvolvimento econômico e do jogo político estadual sobre as taxas de migração. O segundo eixo tem como foco a constituição dos sistemas partidários locais, buscando analisar as características da migração e manutenção entre os partidos e blocos ideológicos nos municípios. Por fim, o terceiro eixo se orienta por um debate sobre a representação ao analisarmos a direção da migração entre os partidos de candidatos eleitos nos pleitos municipais.

O primeiro achado repousa na evidência de que a variação nas taxas de migração dos municípios decorre da dinâmica e das características do jogo político nos estados. Tal conformação determina uma maior ou menor concentração de partidos efetivos em cada unidade da federação, o que faz com que existam diferentes configurações de oportunidades aos candidatos de opetar por mudar de agremiação. Ao mesmo tempo, como hipótese, estados que concentram um menor número de partidos efetivos podem ter uma maior predisposição a terem candidatos fiéis aos partidos de origem, como efeito de uma consolidação de uma tradição ao longo do tempo e da inteligibilidade do sistema partidário estadual. Podemos verificar essa dinâmica nos estados do Rio Grande do Sul e Santa Catarina, que possuem as menores taxas de migração em todos os quesitos analisados.

Ao contrário de Diniz (2000) e Melo (2004), encontramos uma relação entre desenvolvimento econômico dos municípios, região e migração. Encontramos as maiores taxas de migração no Nordeste e as menores no Sul como o resultado da dinâmica do jogo político estadual, mas notamos que independentemente de onde estejam, há predisposição de os municípios mais pobres possuírem taxas de migração maiores. Muito disso pode estar relacionado não apenas aos processos tardios de desenvolvimento e implantação dos partidos nessas localidades (Braga 2006), mas também aos modos como ainda se constitui a dinâmica política local. Avelar e Walter (2008) chamam atenção para mudanças estruturais que tem acontecido nesses municípios - urbanização, crescimento demográfico, industrialização e aumento na escolaridade, principalmente. Porém, as autoras concluem que, em termos de atuação política, os laços partidários e o 
personalismo ainda se encontram fortemente presentes, colocando essas regiões em um processo lento de estruturação partidária.

Sobre o sistema partidário local mostramos que os menores partidos de direita tendem a preservar poucos seus quadros e a manter uma alta taxa de migração, evidenciando baixa característica programática e dificuldade de estruturação ao longo do tempo. Os partidos menores de esquerda e o PT, ao contrário, apresentam maiores taxas de preservação dos quadros com poucas opções de chegada e saída de candidatos. Os grandes partidos, com exceção do PT, tendem a preservar mais seus quadros e, ao mesmo tempo, recebem muitos candidatos de outros partidos. De maneira geral, mostramos que a manutenção dos quadros se relaciona ao modo como os partidos se constituem, em uma interação entre sua estrutura e força programática. No entanto, a migração e sua direção tendem a estar ancoradas na estrutura e no contexto político local e menos na força programática e ideológica dos partidos. Sugerimos que as trocas verificadas entre todos os partidos do sistema partidário nacional são resultado das múltiplas realidades políticas municipais de um país como o nosso. A partir de um ponto de vista macro, não enxergamos padrões nas trocas de agremiação entre candidatos eleitos nos municípios que fossem ancoradas sobre uma perspectiva ideológica determinada a priori.

Nossa hipótese explicativa é que as realidades partidárias nos municípios obedecem a uma lógica contextual própria, que é influenciada pela conformação do jogo político estadual, mas tem pouca relação com uma unidade programática e ideológica dos partidos em âmbito nacional. Nesse sentido, podemos entender que a conformação dos sistemas partidários locais se dá por lógicas e padrões de comportamento próprios, levando-nos a compreender a organização partidária sob um novo prisma: como um elemento fundamental para a consolidação das estratégias de lideranças locais ou regionais. Nesse sentido, os dados não nos permitem dizer que os partidos atuam de maneira coordenada, a partir de um recorte ideológico, por exemplo, que orientaria o jogo político nos municípios a partir da esfera nacional.

IMarco Antonio Faganello (marcofaga@gmail.com) é Doutorando em Ciência Política pela UNICAMP e membro do Grupo de Estudos em Política Brasileira (PolBras), vinculado ao Centro de Estudos de Opinião Pública (CESOP), da mesma universidade. Vínculo Institucional: Programa de Pós-Graduação em Ciência Política, UNICAMP, Campinas, SP, Brasil.

IIJean Lucas Macedo Fernandes (jeanlucasmf@gmail.com) é Doutorando em Ciência Política pela UNICAMP e membro do Grupo de Estudos em Política Brasileira (PolBras), vinculado ao Centro de Estudos de Opinião Pública (CESOP), da mesma universidade. Vínculo Institucional: Programa de Pós-Graduação em Ciência Política, UNICAMP, Campinas, SP, Brasil.

\section{Referências}

Ames, B., 1994. A organização partidária local nas eleições presidenciais brasileiras de 1989. Dados, 37(1), pp.5-41. 2003. Os entraves da democracia no Brasil. Rio de Janeiro: FGV.

Avelar, L. \& Walter, M.I.M.T., 2008. Lentas mudanças:o voto e a política tradicional. Opinião Pública, 14(1), pp.96-122. DOI: $10.1590 / \mathrm{s} 0102-64452000000100011$

Borges, A., 2010. Já não se fazem mais máquinas políticas como antigamente: competição vertical e mudança eleitoral nos estados brasileiros. Revista de Sociologia e Política, 18(35), pp.167-188. DOI: 10.1590/s0104-44782010000100011

Braga, M.S.S., 2006. O processo partidário-eleitoral brasileiro: padrões de competição política (1982-2002). São Paulo: Humanitas/Fapesp.

Braga, M.S.S.; Rodrigues-Silveira, R. \& Borges, T., 2012. Organización, território y sistema partidário: difusión territorial de la organización de los partidos y sus potenciales impactos sobre la estrutura del sistema partidário em Brasil. América Latina Hoy, 62, pp.15-45.

Carneiro, L.P. \& Almeida, M.H.T., 2008. Definindo a arena política local: sistemas partidários municipais na federação brasileira. Dados, 51(2), pp.403-432. DOI: 10.1590/s0011-52582008000200006

Codato, A.; Bolognesi, B. \& Roeder, K.M., 2015. A nova direita brasileira: uma análise da dinâmica partidária e eleitoral do campo conservador. In S.V. Cruz; A. Kaysel \& G. Codas, eds. Direita, volver!: o retorno da direita e o ciclo político brasileiro. São Paulo: Perseu Abramo. 
Cox, G., 1997. Making Votes Count: Strategic Coordination in the World's Electoral Systems. Cambridge: Cambridge University Press.

Desposato, S.W., 2006. Parties for Rent? Ambition, Ideology, and Party Switching in Brazil's Chamber of Deputies. American Journal of Political Science, 50(1), pp.62-80. DOI: 10.1111/j.1540-5907.2006.00170.x

Diniz, E., 1982. Voto e máquina política: patronagem e clientelismo no Rio de Janeiro. Rio de Janeiro: Paz e Terra. , 2000. As migrações partidárias e o calendário eleitoral. Revista de Sociologia e Política, 15, pp.31-47. DOI: 10.1590/s0104-44782000000200003

Figueiredo, A. \& Limongi, F., 1995. Partidos políticos na Câmara dos Deputados: 1989-1994. Dados, 38(3), pp.497-529.

Freitas, A., 2008. Migração Partidária na Câmara dos Deputados. Dissertação de Mestrado. São Paulo: Universidade de São Paulo.

, 2012. Migração Partidária na Câmara dos Deputados de 1987 a 2009. Dados, 55(4), pp.951-986. DOI: $10.1590 / \mathrm{s} 0011-52582012000400004$

Jacomy, M. et al., 2014. ForceAtlas2, a Continuous Graph Layout Algorithm for Handy Network Visualization Designed for the Gephi Software. PLoS ONE, 9(6). DOI: 10.1371/journal.pone.0098679

Kerbauy, M.T.M., 2005. As câmaras municipais brasileiras: perfil de carreira e percepção sobre o processo decisório local. Opinião Pública, 11(2), pp.337-365. DOI: /10.1590/s0104-62762005000200003

Kinzo, M.D.G., 1988. Oposição e autoritarismo: gênese e trajetória do MDB (1966-1979). São Paulo: IDESP/Vértice. 1993. Radiografia do quadro partidário brasileiro. São Paulo: Fundação Konrad-Adenauer-Stiftung.

Krause, S.; Ferreira, D.P.; Ribeiro, P.F \& Melo, P.V., 2016. Fragmentação das eleições locais e o surgimento de novas forças políticas no Brasil. In A. Lavareda \& H. Telles, eds. A lógica das eleições municipais. Rio de Janeiro: FGV.

Lamounier, B., ed., 1994. De Geisel a Collor: o balanço da transição. São Paulo: Papirus.

Lamounier, B. \& Meneguello, R., 1986. Partidos políticos e consolidação democrática: o caso brasileiro. São Paulo: Brasiliense.

Laver, M. \& Benoit, K., 2003. The Evolution of Party Systems between Elections. American Journal of Political Science, 47(2), pp.215-233. DOI: $10.2307 / 3186134$

Lima Júnior, O.B., 1993. Democracia e instituições políticas no Brasil dos anos 80. São Paulo: Loyola. , 1997. Instituições políticas democráticas: o segredo da legitimidade. Rio de Janeiro: Jorge Zahar.

Mainwaring, S., 1991. Políticos, partidos e sistemas eleitorais. Novos Estudos, 29, pp.34-58. 1999.Rethinking Party Systems in the Third Wave of Democratization.The Case of Brazil. Stanford: Stanford University Press.

Mainwaring, S.; Meneguello, R. \& Power, T., 2000. Partidos conservadores no Brasil contemporâneo: quais são, o que defendem, quais são suas bases. São Paulo: Paz e Terra.

McElroy, G., 2003. Party Switching in the European Parliament: Why Bother? In Meeting of the European Consortium for Political Research. Marburg.

Melo, C.R., 2004. Retirando as cadeiras do lugar: migração partidária na Câmara dos Deputados (1985-2002). Belo Horizonte: UFMG.

Miguel, L.F., 2010. Os partidos brasileiros e o eixo esquerda-direita. In S. Krause; H. Dantas \& L.F. Miguel, eds. Coligações partidárias na nova democracia brasileira: perfis e tendências. São Paulo/Rio de Janeiro: Unesp/Konrad-Adenauer.

Nicolau, J., 1996. A migração partidária na Câmara dos Deputados (1991-1996). Monitor Público, 10, pp.41-45.

Power, T. \& Zucco Jr., C., 2009. Estimating Ideology of Brazilian Legislative Parties, 1990-2005: A Research Communication. Latin American Research Review, 44(1), pp.218-246. DOI: 10.1353/lar.0.0072 ,2011. O congresso por ele mesmo: autopercepções da classe política brasileira. Belo Horizonte: UFMG.

Schmitt, R., 1999. Migração partidária e reeleição na Câmara dos Deputados. Novos Estudos, 54, pp.127-146.

Singer, A., 2002. Esquerda e direita no eleitorado brasileiro: a identificação ideológica nas disputas presidenciais de 1989 e de 1994. São Paulo: Edusp.

Trounstine, J., 2009. All Politics Is Local: The Reemergence of the Study of City Politics. Perspectives on Politics, 7(3), p.611. DOI: $10.1017 / \mathrm{s} 1537592709990892$

Vasquez, V., 2016. Ao vencedor, a prefeitura: competição em eleições municipais (1996-2012). Dissertação de Mestrado. Campinas: Universidade Estadual de Campinas. 
Party migration in Brazilian municipalities (2000-2016)

ABSTRACT Introduction: The aim of this article is to explore party migration dynamics at local level, between 2000 and 2016, focusing on mayor and city councilor elections in Brazil. There is a lot of studies about party migration at national level, especially about Congress. However, at local level the phenomena does not receive the same attention. Methods: Methodology used is all quantitative, taking information from Tribunal Superior Eleitoral (TSE), and using tools like electoral geography, network analysis and descriptive statistics. Results: Party migration does not bring, necessarily, more electoral success. The article also show that, at local level, migration taxes are decaying. Discussion: In general, literature says that parties have "weak" connections with their candidates, in the cities. Parties would be changed all the time by politicians, whenever the context were favorable. From this point of view, party migration at the municipal level would be determined by circumstantial factors. However, the findings obtained in this article reveal that there are patterns of behavior of candidates and parties in municipalities in terms of electoral strategies, and that the variation in migration indicators is not ad hoc. In this way, we point to another reality: parties can follow distinct and coordinated strategies, when it is about switching or not.

KEYWORDS: political parties; municipalities; local politics; mayors; city councilours.

This is an Open Access article distributed under the terms of the Creative Commons Attribution Non-Commercial License which permits unrestricted non-commercial use, distribution, and reproduction in any medium provided the original work is properly cited. 


\section{Apêndice}

Tabela 1A - Lista de siglas

\begin{tabular}{|c|c|}
\hline Sigla & Nome por extenso \\
\hline ARENA & Aliança Renovadora Nacional \\
\hline DEM & Democratas \\
\hline MDB & Movimento Democrático Brasileiro \\
\hline PAN & Partido dos Aposentados da Nação \\
\hline PCB & Partido Comunista Brasileiro \\
\hline PCdoB & Partido Comunista do Brasil \\
\hline $\mathrm{PCO}$ & Partido da Causa Operária \\
\hline PDT & Partido Democrático Trabalhista \\
\hline PEN & Partido Ecológico Nacional \\
\hline PFL & Partido da Frente Liberal \\
\hline PHS & Partido Humanista da Solidariedade \\
\hline PMDB & Partido do Movimento Democrático Brasileiro \\
\hline PMN & Partido da Mobilização Nacional \\
\hline PL & Partido Liberal \\
\hline PP & Partido Progressista \\
\hline PPB & Partido Progressista Brasileiro \\
\hline PPL & Partido Pátria Livre \\
\hline PPS & Partido Popular Socialista \\
\hline PR & Partido da República \\
\hline PRB & Partido Republicano Brasileiro \\
\hline PRONA & Partido da Reedificação da Ordem Nacional \\
\hline PRP & Partido Republicano Progressista \\
\hline PRTB & Partido Renovador Trabalhista Brasileiro \\
\hline PSB & Partido Socialista Brasileiro \\
\hline PSC & Partido Social Cristão \\
\hline PSD & Partido Social Democrático \\
\hline PSDB & Partido da Social Democracia Brasileira \\
\hline PSDC & Partido Social Democrata Cristão \\
\hline PSL & Partido Social Liberal \\
\hline PSOL & Partido Socialismo e Liberdade \\
\hline PSTU & Partido Socialista dos Trabalhadores Unificado \\
\hline PT & Partido dos Trabalhadores \\
\hline РTB & Partido Trabalhista Brasileiro \\
\hline PTC & Partido Trabalhista Cristão \\
\hline PTdoB & Partido Trabalhista do Brasil \\
\hline PTN & Partido Trabalhista Nacional \\
\hline PV & Partido Verde \\
\hline
\end{tabular}

Fonte: Tribunal Superior Eleitoral. 